\title{
ECONOMICS
}

\section{EXPORT WAGE PREMIUM IN CHINA'S MANUFACTURING SECTOR: A FIRM LEVEL ANALYSIS}

by

Dahai Fu

and

Yanrui Wu

Business School

University of Western Australia 


\title{
EXPORT WAGE PREMIUM IN CHINA'S MANUFACTURING SECTOR: \\ A FIRM LEVEL ANALYSIS
}

\author{
Dahai Fu and Yanrui Wu \\ dahai.fu@yahoo.com and yanrui.wu@uwa.edu.au \\ Economics, \\ Business School \\ University of Western Australia \\ 35 Stirling Highway, Crawley, WA6009 \\ Australia
}

DISCUSSION PAPER 11.22

\begin{abstract}
:
This paper investigates whether exporting firms in Chinese manufacturing sector pay higher average wages than non-exporting firms by analyzing a large firm-level dataset derived from the Chinese Industrial Census in 2004. Through rigorous exercises involving robust regressions, quantile regressions and nonparametric matching estimators, we find that the wage premium of exporting activities is not a prevailing phenomenon in China. It is highly associated with heterogeneous characteristics of firms, such as ownership, export-orientation and locations. Overall, exporters located in coastal regions but Guangdong province are more likely to pay higher average wages than nonexporters, while those producing in Guangdong on average offer a lower pay.
\end{abstract}

Keywords: Export; Wage premium; Manufacturing; China

JEL: F16; J31; L6 


\section{Introduction}

The rise in inequality, whether measured in terms of income or wages, has been observed in both developed and developing countries over the last three decades (Wood, 2002; Goldberg and Pavcnik, 2007). According to the prediction of the traditional Hecksher-Ohlin theory, however, the opposite should be expected to happen in developing countries following major trade reforms. This contradiction has discouraged economists from conducting research on the relationship between trade and inequality. To explain rising inequality, economists instead look for other factors, such as skillbiased technological change, immigration, unions and others. However, recent evidence at the firm level and developments of theoretical models incorporating heterogeneity of firms and workers and labour market imperfections have renewed researchers' interest in the link between trade and inequality (e.g. Egger and Kreickemeier, 2009; Helpman et al., 2010).

One of the important insights gained in recent studies is that the potential effect of trade on wage inequality is reflected in the wage gap between exporters and nonexporters. A large number of studies using firm level data from different countries have shown the existence of export wage premia, that is, exporting firms pay higher wages than firms supplying the domestic market only. ${ }^{1}$ As pointed out by Baumgarten (2010), this wage gap can affect total wage inequality over time via two channels. First, the share of employment in exporting firms may change due to the expansion of existing exporters or the entry of new exporters. Second, the size of the wage gap itself may change because of increasing internationalization. Therefore, examining the wage differentials between exporters and nonexporters could help us understand the impact of trade on inequality.

Although the existing literature has shown the existence of an export wage premium in many countries, there is little information about Chinese enterprises. The present paper aims to fill this gap by exploring whether exporters pay higher average wages than nonexporters in China. The empirical analyses are based on a very rich enterprise census dataset collected in 2004 and covering all Chinese manufacturing enterprises. China is particularly interesting since it is not only the largest developing country with abundant low-cost labour but also a major trading nation in the world. Since the implementation of the 'open-door' policy in the early 1980s, China's exports grew from US\$14 billion in 1979 to US\$1,578 billion in 2010, while the ratio of exports to GDP increased from 0.06 to 0.26 during the same period. In 2009, China overtook Germany to become the largest merchandise exporter. Since 1979, along with the rapid growth in national income and export volume, China also has witnessed rising wage inequality (Xu and $\mathrm{Li}, 2008)$. According to a recent report by OECD (2010), the Gini coefficient of per capita income in China between 1993 and 2008 increased by 24\%, which was higher than that in India (16\%), South Africa (4.5\%) and OECD countries (5.5\%).

\footnotetext{
${ }^{1}$ For a survey of the literature, see Schank et al. (2007).
} 
This study contributes to the growing literature on the export wage premium. It differs from previous studies in two ways. First, we provide new evidence at the firm level from the perspective of a large open developing country. As much of the existing empirical research has been carried out using data from either developed countries or small developing economies, a case study of Chinese firms would be unique and hence add to the existing literature. Second, we pay particular attention to the relationship between export wage premium and firms' ownership and location. In the existing papers, multinational enterprises of different country origin and locally owned enterprises of different ownership are treated as a whole. In contrast, this study breaks down the data by ownership and allows for the export wage premium to vary across firms of different ownership. We also carefully consider the influence of firms' location on the premium, for we believe that firms located in different provinces could behave differently due to variations in resource endowments and local government policies.

Our empirical regression analyses reveal the following three main findings. First, exporting firms except for those from Hong Kong, Macau and Taiwan (HMT) are more likely to pay higher average wages than their nonexporting counterparts in general, although the magnitude of the wage gap varies according to the distribution of wages as demonstrated by the results of quantile regressions. Second, the wage premia of exporters are more likely to be associated with firms producing for both foreign and domestic markets while those exporting only tend to pay a lower average wage. Third, exporting firms located in east China are more likely to offer a wage premium, while those based in Guangdong offer lower average wages than nonexporters. It is also found that exporting firms operating in Jiangsu province pay higher average wages than nonexporting firms.

The remainder of the paper is structured as follows. Section 2 presents a review of the theoretical concepts and empirical literature. This is followed by a discussion of the modeling issues in Section 3. The data issues and preliminary analyses are described in Section 4 with Section 5 discussing the empirical results. The final section, Section 6, presents the conclusion.

\section{Literature Review}

\subsection{Theoretical concepts}

The theoretical explanation for the effect of trade on wages and wage disparity originates from the standard Hecksher-Ohlin trade model or more precisely the Stopler-Samuelson theorem. The latter implies that trade increases income inequality in rich countries and reduces income inequality in poor countries. This conclusion is at odds with the reality. Many economists recently thus try to relax the assumptions of the traditional trade models, such as frictionless labour markets, identical firms, homogenous workers and free mobility of workers within a country. 
The new theories based on the heterogeneous firm trade model by Melitz (2003) provide insights into the effect of trade on income and wage inequality. One of the theories is the so-called fair wage model along the lines of Akerlof and Yellen (1990). Egger and Kreickemeier (2009) introduced labor imperfections into a heterogeneous-firm trade model by means of a fair wage effort mechanism. In their framework, workers care about receiving 'fair wages' and whether the wages are considered to be fair by workers depends on the economic success of the firm where they are working. The fair wage preferences lead workers to feel entitled to be paid higher wages when they work at more productive and profitable firms. Otherwise, workers would withhold their efforts. Exporting firms that are more productive and profitable than nonexporting firms then pay higher wages in the equilibrium. The equilibrium of this framework hence features wages that differ from firm to firm, and also, in general, positive unemployment.

A second heterogeneous firm approach to trade and wage inequality was proposed by Helpman, Istkhoki and Redding (2010). They introduced searching and matching frictions and employer screening into the Melitz-type model. In their framework, because of the hiring cost, workers outside a firm are not perfect substitutes for workers currently employed, and employed workers are able to bargain for a share of profits. Workers are ex-ante homogenous but receive a firm-specific ability draw. The complementarities between employees' abilities and firm productivity provide the incentive for firms to screen workers. More productive firms which would select to export screen more intensively to exclude those with lower ability and hence have workforces with higher average ability. Since higher-ability employees are more costly to replace, more productive firms thus need to pay higher wages. Trade liberalization would allure more productive firms into exporting, which further enhances their incentive to screen workers. Based on this logic, exporters would have workforce with higher average ability than nonexporters and hence pay higher wages.

Another related approach is explored by Davis and Harrigan (2007) who offered a shirking effort model following the monitoring approach of Shapiro and Stiglitz (1984). If workers' effort cannot be monitored perfectly, higher wages make the threat of being fired when caught shirking more credible. In their approach, firms differ from each other not only in the marginal product of labor as in Melitz model, but also in the probability of detecting a shirking worker. This implies that the average wage paid varies among the firms with those that are good at catching shirkers paying low wages and firms that are bad at catching shirkers paying high wages. Accordingly, if a worker's effort is more valuable to an exporting firm or less perfectly monitored, the exporting firm will pay a higher wage. For example, Verhoogen (2008) proposed a quality-upgrading mechanism linking trade and wage inequality in developing countries. The author argued that more productive exporters produce higherquality goods than less productive nonexporters, and hence pay higher wages to maintain a higherquality workforce. Finally, Yeaple (2005) hypothesized that modern technologies are worse at 
monitoring effort than traditional technologies, and hence concluded that the exporting-induced adoption of modern technologies leads to higher wages.

\subsection{Empirical evidence}

The export wage premium has been supported by a large body of empirical literature on both developed and developing countries although the estimated premium varies across the countries. For example, there is empirical evidence from the United States (Bernard and Jensen, 1997), Germany (Bernard and Wagner 1997), and the United Kingdom (Greenaway and Yu, 2004). The derived positive wage premia in these studies range from $2.6 \%$ to $6.4 \%$. In these empirical exercises, the authors all ran the regressions of average annual wage against the exporter status, controlling for capital per worker, firm size, age, location and other firm-specific characteristics.

The studies on developing nations also show positive wage premia which appear to be larger than those in developed countries. For instance, Alvarez and Lopez (2005) found an export premium of 21\% for average wages in Chile. Similarly, Van Biesebroeck (2005) showed that export wage premia for Sub-Saharan African nations are statistically significant and about $40 \%$ after controlling for country, year, industry, location and plant size. However, some authors point out that the preceding studies could overstate the wage premia without controlling for individual worker characteristics or the skill structure of the workforce within firms (Munch and Skaksen, 2008). This is because the wage gap between exporters and nonexporters may result from either exporting activities or the different types of employment between them.

More recent models are able to differentiate the export wage premia for workers with different skill levels or take employment characteristics into account. Tsou et al. (2006) found a positive export wage premium for skilled workers and a negative export wage premium for unskilled workers in Taiwanese manufacturing firms. Hansson and Lundin (2004) also found wage premia for skilled workers in Swedish manufacturing firms. A growing number of studies use matched employeremployee data to control for worker attributes in addition to firm characteristics in analysing export wage premia. For instance, Schank et al. (2007) used a large dataset of manufacturing firms and workers from Germany between 1995 and 1997 and they showed that the wage premia become smaller when observable and unobservable characteristics of the employees and workplaces were controlled for. They also found a higher export wage premium for blue collar workers than that for white collar workers. Munch and Skaksen (2008) linked the export wage premia to the use of human capital in Danish exporting firms and found the existence of export wage premia only in the exportintensive firms with workers who have higher levels of education. Breau and Rigby (2006), in contrast, failed to find wage premia of exporting firms in Los Angeles of the U.S. after controlling for worker characteristics such as age, gender, education, race, and nationality. 
Despite the fact that China has experienced a sharp increase in wage inequality, its causes at the micro level are underdocumented. Using Chinese urban household survey data, Zhao (2001) investigated the effects of foreign direct investment on wage inequality. Using a sample of 1,500 firms in five cities in China for the period 1998-2000, Xu and Li (2008) attribute the county's fast growing income inequality to the rising demand for skilled labour. They showed that export expansion had a negative direct effect on skill demand and a positive indirect effect via skill-biased technologies. The net effect is estimated to account for $5 \%$ of the rising skill demand of the sampled firms. Chen et al. (2011) investigated the link between foreign direct investment and inter-firm wage inequality. Their results imply that the wage level and growth rate in multinationals are significantly higher than those in domestic firms. In a recent paper, Bao (2011) employed the matching technique and difference-in-difference estimator to analyse a small sample (456 firms) of Chinese manufacturing firms covering the period of 1998-2001 and he found that the export decision of firms does not cause high wages of employees in the subsequent years. In his paper Bao did not consider the impact of employment structure due to the constraint of data.

\section{Modelling Issue}

\subsection{The model}

We aim to test whether exporting firms pay higher average wages than nonexporting firms. Following the best practice in the literature, we consider a standard Mincerian wage equation:

$$
\begin{aligned}
\mathrm{w}_{\mathrm{i}}= & \alpha+\beta_{1} \operatorname{Exp}_{\mathrm{i}}+\beta_{2} \text { For }_{\mathrm{i}}+\beta_{3} \operatorname{Exp}_{\mathrm{i}} \times \text { For }_{\mathrm{i}} \\
& +\beta_{4} \mathrm{LP}_{\mathrm{i}}+\beta_{5} \text { Size }_{\mathrm{i}}+\beta_{6} \text { Age }_{\mathrm{i}}+\beta_{7} \mathrm{KL}_{\mathrm{i}} \\
& +\beta_{8} \mathrm{Fem}_{\mathrm{i}}+\sum \lambda_{\mathrm{s}} \text { Skill }_{\mathrm{is}}+\sum \delta_{\mathrm{j}} \text { Province }_{\mathrm{ij}}+\sum \vartheta_{\mathrm{k}} \text { Industry }_{\mathrm{ik}}+\varepsilon_{\mathrm{i}}
\end{aligned}
$$

where $\mathrm{w}_{\mathrm{i}}$ denotes the logarithm of the average wage of enterprise $i$. Exp $\mathrm{p}_{\mathrm{i}}$ denotes the firm's exporting status, which equals one if its records show positive exports in 2004 and zero otherwise. For $_{i}$ is an ownership dummy that is equal to one if the firm is foreign-funded (including Hong Kong, Macau and Taiwan-funded), taking domestic firms as the base group. To capture the differences in export wage premia among foreign firms and domestic firms, we add an interaction term between exporting status and foreign firms dummy variable. $\mathrm{LP}_{\mathrm{i}}$ is the labour productivity, which is defined as the logarithm of output per worker. Size $\mathrm{i}_{\mathrm{i}}$ is the logarithm of total assets of enterprise i. Age $\mathrm{i}_{\mathrm{i}}$ represents the firm's business history since its establishment. $\mathrm{KL}_{\mathrm{i}}$ is the capital-labour ratio which is defined as the net value of fixed assets divided by the number of employees in firm $i . F_{\mathrm{i}}$ is the share of the number of female workers over the total number of employees. Skill is is the skill composition of the employees in enterprises $i$, and is measured by three different variables $(s=1,2,3)$ : 
the proportion of employees with a graduate education (18 years of education and over), the proportion of employees with a college education (16 years of education), and the proportion of employees with a high school education (12 years of education). According to the existing studies, $\mathrm{Fem}_{\mathrm{i}}$ is expected to have a negative impact on the average wage and the skill composition has a positive impact due to the skill premium (Chen et al., 2011). Province ${ }_{\mathrm{ij}}$ is a province dummy that is equal to one if enterprise $i$ is located in province $j$, and zero otherwise, and is supposed to capture region-specific wage differentials. Industry ${ }_{\mathrm{ik}}$ is an industry dummy that is equal to one if firm $i$ operates in industry $k$, and zero otherwise, and is expected to reflect industry-specific wage differentials. $\alpha$ is a constant and $\varepsilon_{\mathrm{i}}$ is the error term.

\subsection{Estimation issues}

Given firm level cross-sectional data considered here, we first use the ordinary least squares (OLS) method to estimate the wage equation (1). We are aware that the adopted regression analysis might not be appropriate because of possible omitted variable biases (Wooldridge, 2000, p.91). Therefore, the results of OLS regression analyses should be interpreted with caution. The estimated coefficient $\hat{\beta}_{1}$ represents the wage premium of domestic exporters, while the sum of the estimated coefficients $\left(\hat{\beta}_{1}+\hat{\beta}_{3}\right)$ measures the wage differentials between foreign exporters and foreign nonexporters. The above analysis could suggest a relationship between wage level and exporting status.

However, we notice that the main concern of the OLS regressions is that the average wage gap is not representative of the wage differentials among different quantiles of the wage distribution. For instance, if more talented and high-ability workers would tend to be hired by exporting firms, the average wage of exporting firms would be driven up and the export wage premia would be overestimated. To identify the effects of unobservable ability of workers on wages, the use of quantile regression analysis has become increasingly popular in labour economics particularly in studies of wage differentials with respect to education, gender and working condition (Choi and Jeong, 2007). Following these practice, we use quantile regressions to examine the possibility that the impact of exporting activities on average wages could vary as the distribution of the dependent variables (wages) changes.

The quantile regression technique was first introduced by Koenker and Bassett (1978). In contrast to the OLS method which provides information only about the effect of regressors on the conditional mean of the dependent variable, the results of quantile regression analysis give parameter estimates at different quantiles, $\tau$. Thus, the results of quantile regressions could give us a more detailed picture of the export wage premium in China. Symbolically, our quantile regression model is: 


$$
\begin{aligned}
& \mathrm{w}_{\mathrm{i}}=\beta_{\tau}^{\prime} \mathrm{X}_{\mathrm{i}}+\mathrm{u}_{\tau \mathrm{i}} \\
& \text { with } \mathrm{Q}_{\tau}\left(\mathrm{w}_{\mathrm{i}} \mid \mathrm{X}_{\mathrm{i}}\right)=\beta_{\tau}^{\prime} \mathrm{X}_{\mathrm{i}} \quad(\mathrm{i}=1,2, \ldots, \mathrm{n})
\end{aligned}
$$

where $\mathrm{w}_{\mathrm{i}}$ is the vector of log wage, $\beta_{\tau}^{\prime}$ is a $(\mathrm{Kx} 1)$ parameter vector, $\mathrm{X}_{\mathrm{i}}$ is a $(\mathrm{Kx} 1)$ vector of covariates, $\mathrm{u}_{\tau i}$ stands for the error term and $\mathrm{Q}_{\tau}\left(\mathrm{w}_{\mathrm{i}} \mid \mathrm{X}_{\mathrm{i}}\right)$ denotes the $\tau^{\text {th }}$ conditional quantile of $\mathrm{w}_{\mathrm{i}}$ given $\mathrm{X}_{\mathrm{i}}$. Note that $\mathrm{Q}_{\tau}\left(\mathrm{u}_{\tau \mathrm{i}} \mid \mathrm{X}_{\mathrm{i}}\right)=0$ for all $i$. For a given $\tau$, the quantile regression estimator of $\beta_{\tau}$ is a solution to

$$
\min _{\beta} \frac{1}{\mathrm{n}}\left\{\sum_{\mathrm{w}_{\mathrm{i}} \geq \beta_{\tau}^{\prime} \mathrm{X}_{\mathrm{i}}} \tau\left|\mathrm{w}_{\mathrm{i}}-\beta_{\tau}^{\prime} \mathrm{X}_{\mathrm{i}}\right|+\sum_{\mathrm{w}_{\mathrm{i}}<\beta_{\tau}^{\prime} \mathrm{X}_{\mathrm{i}}}(1-\tau)\left|\mathrm{w}_{\mathrm{i}}-\beta_{\tau}^{\prime} \mathrm{X}_{\mathrm{i}}\right|\right\}
$$

As $\tau$ increases from 0 to 1 , one can trace the whole distribution of $\mathrm{w}_{\mathrm{i}}$ condition on $\mathrm{X}_{\mathrm{i}}$. The coefficient estimates of a quantile regression capture the effect of covariates on the distribution of the dependent variable at the corresponding quantile and hence we can compare the effects of covariates at different quantiles.

Finally, endogeneity may be present in Equation (1). The orthogonal assumption between exporting dummy and the error term in the OLS estimator could be violated if some omitted variables lead export participation and average wage to move in the same direction. The most convenient way to control for the omitted variables is to use panel data approaches (fixed effects or random effects model) by assuming the omitted variables are time-invariant and hence treating them as part of the error term. However, it is impossible here due to the use of cross-sectional data. An alternative way to deal with endogeneity is to find instrument variables (IVs) that are assumed to be orthogonal to the error term. Unfortunately, in most cases, these IVs are either hard to come by or they are weakly correlated with the endogenous variables. Although Arellano and Bond (1991) suggested using GMM-style IVs out of endogenous variables, it is not suitable for cross-sectional data. To overcome this problem, we here make use of a non-parametric matching method to find the wage differentials between exporting firms and nonexporting firms. The method compares the average wages of exporters with those 'matched' nonexporters. Matching is based on the similarity in observed characteristics of the firms. ${ }^{2}$ One of the main advantages of the matching method is that it does not require the specification of any functional form of the outcome equation and is therefore not susceptible to misspecification bias. ${ }^{3}$

\footnotetext{
${ }^{2}$ Firm characteristics in our analyses include labour productivity, firm size, firm age, capital-labour ratio, female share, graduate share, college share, and high-school share.

${ }_{3}^{3}$ Please see Abadie et al. (2004) for the details about the matching method and Stata module.
} 


\section{Data and Descriptive Statistics}

The dataset used in this paper is drawn from the First National Economic Census conducted by National Bureau of Statistics of China in 2004. To the best of our knowledge, the census provides the most comprehensive cross-sectional enterprise data available in China. The basic statistics included in this dataset are summarized in the China Economic Census Yearbook (National Bureau of Statistic of China, 2006). We only have access to the data for the manufacturing sector, and our analysis thus focuses on this sector only. The database not only covers the whole population of Chinese manufacturing firms but also provides rich information for each firm, such as export sales, geographic location, the year of establishment, ownership, total assets, and total employment. More importantly, it reports detailed information about the workforce by education and gender, which enables us to examine the impact of skill intensity and gender structure on average wages. After cleaning the observations with missing values for the key variables, we obtained a sample of 879,000 firms for our analysis.

Table 1 presents the summary statistics for the variables employed in this paper together with a breakdown by exporting status and types of ownership. It is found that exporting firms on average pay $15.3 \%$ higher than nonexporting firms. It is also found that foreign exporters on average pay less than foreign nonexporters when we break the whole sample into domestic firms and foreign firms. However, the average wages of foreign firms are found to be much higher than those of domestic firms. The descriptive statistics also reveal that exporters on average are larger than nonexporters in terms of total employment, sales and total assets. With respect to the capital-labour ratio, exporters are on average more capital-intensive than nonexporters while foreign exporters are less capital-intensive than foreign nonexporters. Surprisingly, we notice that, contrary to the popular perception, exporting firms on average are shown to be less productive in terms of output per worker. One possible explanation is that most exporters in China tend to specialize in labour-intensive activities. When comparing the employment structure, we notice that exporters tend to employ more female workers. Both domestic and foreign exporters have employed less skilled labour in terms of the educational attainments of their employees, although the differences among local firms are rather small. 


\section{Table 1}

Summary statistics of the sample.

\begin{tabular}{|c|c|c|c|c|c|c|}
\hline & \multicolumn{2}{|c|}{ Whole sample } & \multicolumn{2}{|c|}{ Domestic firms } & \multicolumn{2}{|c|}{ Foreign firms } \\
\hline & Exporter & Nonexporter & Exporter & Nonexporter & Exporter & Nonexporter \\
\hline Average wage & $9.824 *$ & $8.518^{*}$ & $9.506^{*}$ & $8.438 *$ & $10.339^{*}$ & $11.681^{*}$ \\
\hline (1000 yuan) & (7.119) & $(5.727)$ & $(6.771)$ & $(5.578)$ & $(7.623)$ & $(9.402)$ \\
\hline Number of & $85^{*}$ & $26^{*}$ & $92 *$ & $26^{*}$ & $72 *$ & $41 *$ \\
\hline employees (person) & $(378)$ & (64) & $(476)$ & $(64)$ & $(87)$ & $(52)$ \\
\hline Sales & $15,722 *$ & $2,453 *$ & $23,542 *$ & $2,457 *$ & $3,014 *$ & $2,320 *$ \\
\hline (1000 yuan) & $(309,437)$ & $(31,177)$ & $(393,027)$ & $(31,567)$ & $(8,399)$ & $(3,657)$ \\
\hline Gross capital & $20,147 *$ & $2,679^{*}$ & $28,797 *$ & $2,577 *$ & $6,092 *$ & $6,700^{*}$ \\
\hline (1000 yuan) & $(341,777)$ & $(30,238)$ & $(433,140)$ & $(30,461)$ & $(37,975)$ & $(19,182)$ \\
\hline \multirow[t]{2}{*}{ Capital labour ratio } & $59 *$ & $50 *$ & 45 & 47 & $83 *$ & $162 *$ \\
\hline & $(171)$ & $(354)$ & $(142)$ & $(270)$ & $(208)$ & $(1,470)$ \\
\hline \multirow[t]{2}{*}{ Output per worker } & $94 *$ & $115^{*}$ & $108^{*}$ & $116^{*}$ & $71 *$ & $97^{*}$ \\
\hline & $(157)$ & $(382)$ & $(174)$ & $(386)$ & (119) & $(140)$ \\
\hline Firm age & 7.0 & 6.9 & $7.2 *$ & $7.0 *$ & $6.6^{*}$ & $5.9 *$ \\
\hline (year) & $(8.1)$ & $(7.3)$ & $(9.5)$ & $(7.3)$ & $(4.7)$ & $(4.6)$ \\
\hline Share of female & $0.517^{*}$ & $0.353^{*}$ & $0.515^{*}$ & $0.350^{*}$ & $0.520 *$ & $0.432 *$ \\
\hline workers & $(0.250)$ & $(0.255)$ & $(0.257)$ & $(0.255)$ & $(0.240)$ & $(0.246)$ \\
\hline Share of & $0.003^{*}$ & $0.002 *$ & 0.002 & 0.002 & $0.004 *$ & $0.009^{*}$ \\
\hline postgraduate & $(0.021)$ & $(0.023)$ & $(0.018)$ & $(0.023)$ & $(0.025)$ & $(0.044)$ \\
\hline Share of & $0.083^{*}$ & $0.075^{*}$ & $0.069^{*}$ & $0.072 *$ & $0.107^{*}$ & $0.190^{*}$ \\
\hline college & $(0.141)$ & $(0.156)$ & $(0.128)$ & $(0.152)$ & $(0.156)$ & $(0.234)$ \\
\hline Share of & $0.280^{*}$ & $0.291^{*}$ & $0.271^{*}$ & $0.289^{*}$ & $0.295^{*}$ & $0.339 *$ \\
\hline high-school & $(0.228)$ & $(0.263)$ & $(0.228)$ & $(0.263)$ & $(0.228)$ & $(0.252)$ \\
\hline Observations & 48,572 & 841,582 & 30,069 & 820,627 & 18,503 & 20,955 \\
\hline
\end{tabular}

An overview of the distribution of the exporting firms by their export intensity, measured by the ratio of the value of exports over that of sales, is presented in Fig.1. In our sample, only 5.5 per cent of the firms were involved in exporting activities. However, over a half of the exporting firms shipped 100 per cent of their outputs abroad. This number is even higher for foreign firms $(66 \%)$ and a little bit lower for domestic firms (43\%). This distribution is very different from the manufacturing firms in the United States. Bernard et al. (2003) reported that two-thirds of the US exporters sold less than 10 per cent of their output overseas, and fewer than 5 per cent of them exported more than 50 per cent of their outputs. 


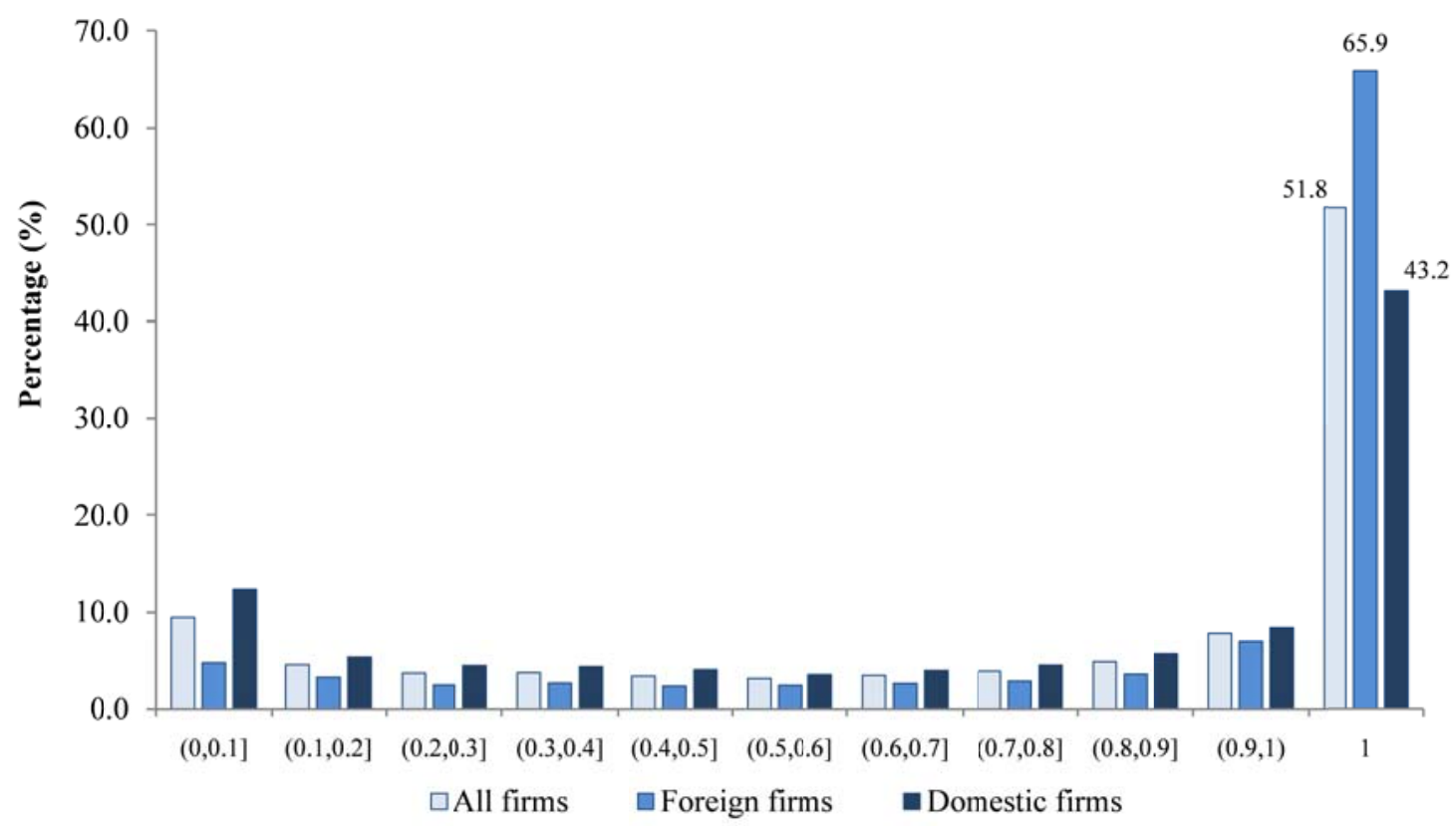

Fig.1. Distribution of exporters by export intensity in 2004.

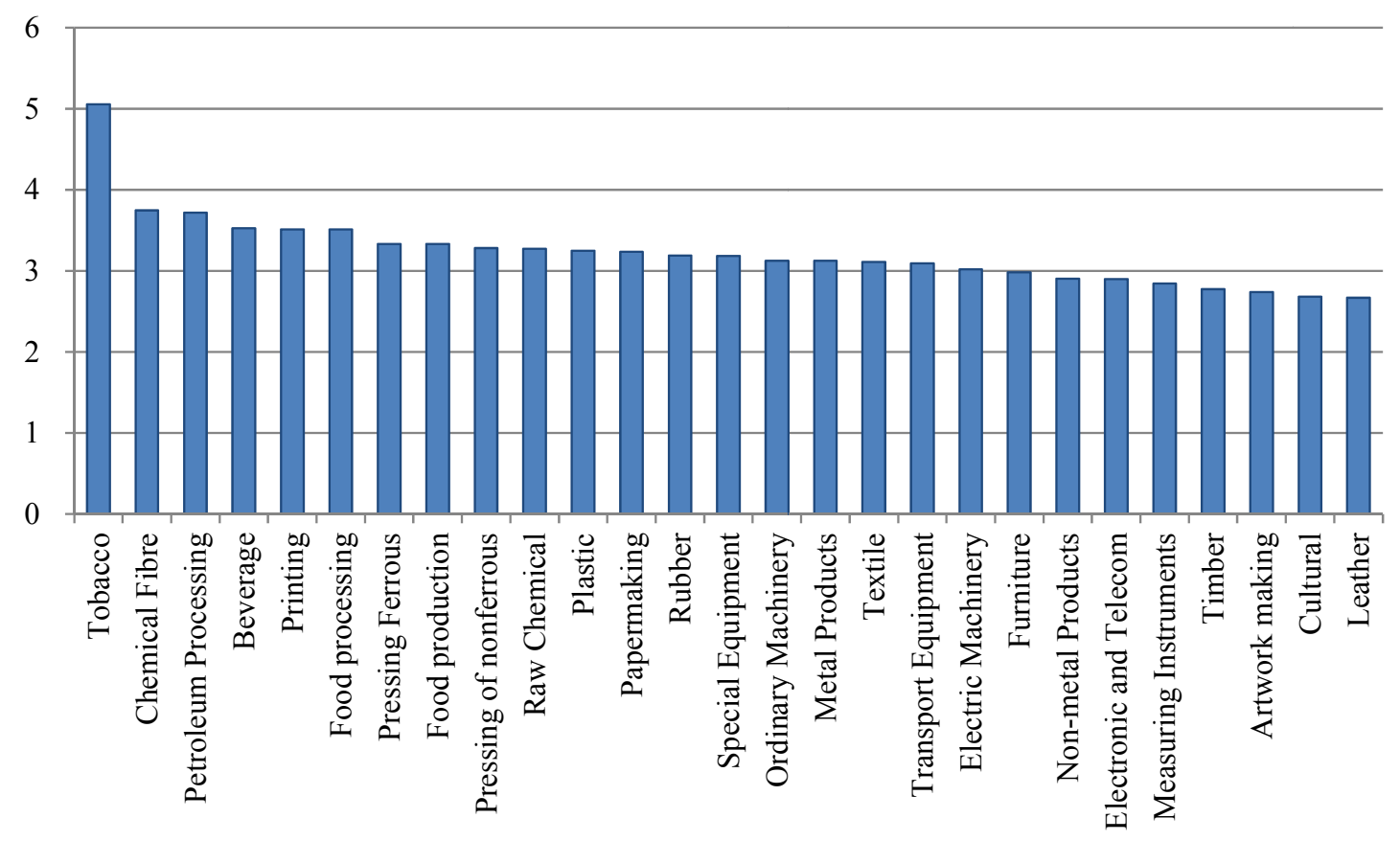

Fig.2. Export wage premium across manufacturing sectors in 2004. 


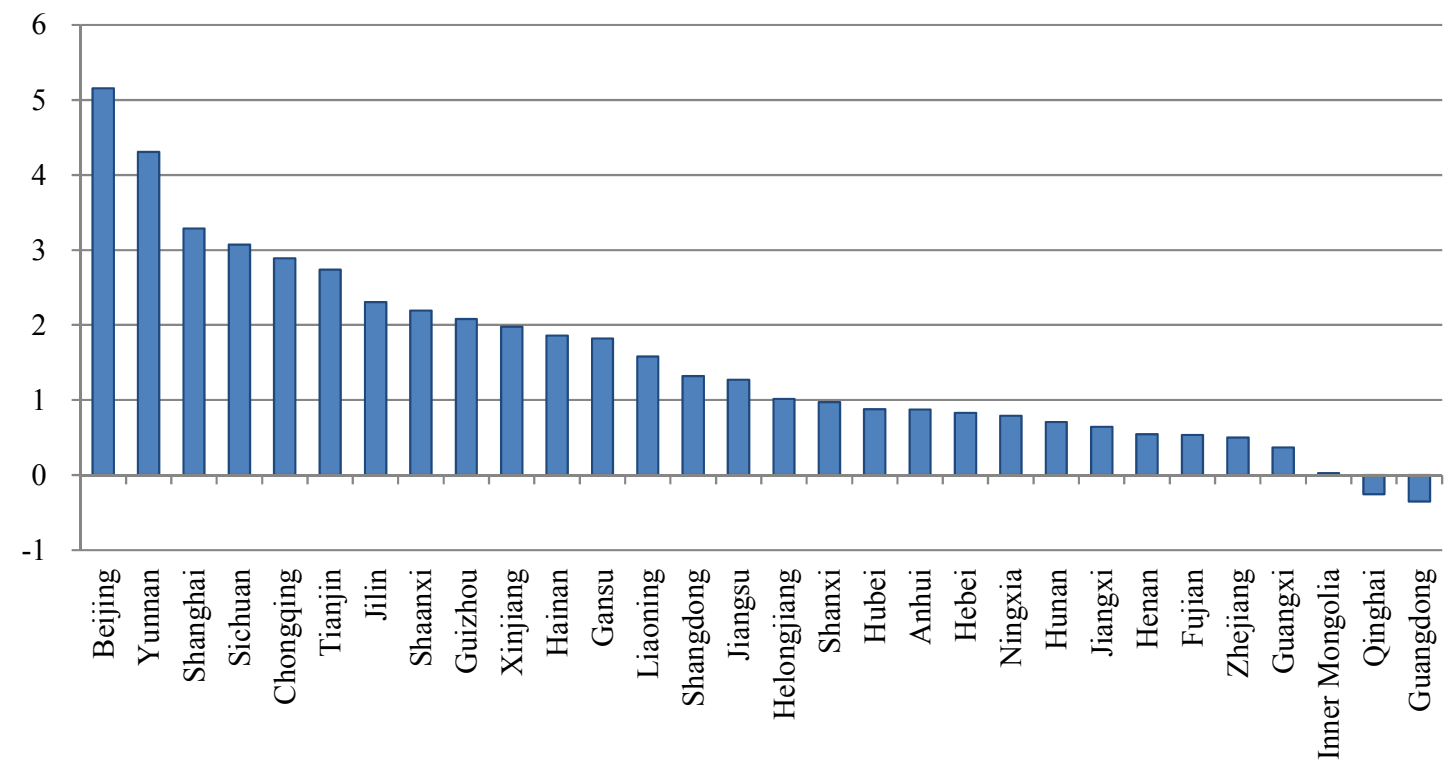

Fig.3. Export wage premium across regions in 2004.

Are export wage premia systematically different across the industries and regions? Figs. 2 and 3 provide the preliminary answers. It is shown that export wage premia, measured as the differences in average log wages between exporters and nonexporters, exist in all industries and vary moderately. While the largest wage gap is observed in the tobacco industry, the smallest wage premium seems to be in the leather and cultural product manufacturing sectors. At the provincial level, there is substantial variation in the wage gap. The largest wage gap between exporters and nonexporters is observed in Beijing, the capital city, which is followed by Yunnan province, a major tobacco production center in the country. However, exporting firms on average pay lower wages than nonexporting firms in Guangdong province. The latter is the largest manufacturing center in China and accounts for over one third of the country's total exports. These findings may imply that the variations in export wage premia are highly correlated with firms' location rather than the industries which the firms are associated with.

\section{Empirical Results}

\subsection{Baseline regressions}

Table 2 reports the baseline regression results. The dependent variable is the logarithm of the average wage for each firm. The Huber-White sandwich estimator was used to correct for possible heteroskedasticity. Regression (1) in Table 2 reports the results from a simple model with three explanatory variables, namely, export dummy, foreign firm dummy and their interaction term. The benchmark category is the non-exporters. The coefficient of the export dummy variable is statistically 
significant, and the positive sign indicates that ceteris paribus exporters on average pay higher wages than nonexporters. The coefficient of foreign firm dummy is also positive and statistically significant at 1 per cent level. Thus on average a foreign wage premium is confirmed. This finding is consistent with the observation by Lipsey and Sjoholm (2003) and Chen et al. (2011). The coefficient of the interaction term between export dummy and foreign firm dummy is significantly negative and its absolute value is larger than the coefficient of export dummy, indicating that the foreign exporters pay less than foreign nonexporters.

\section{Table 2}

Baseline results: OLS regressions.

\begin{tabular}{|c|c|c|c|c|c|c|c|}
\hline & \multicolumn{7}{|c|}{ Dependent variable: $\ln ($ average wage) } \\
\hline & (1) & (2) & (3) & (4) & $(5)$ & (6) & (7) \\
\hline \multirow[t]{2}{*}{ Export dummy $(\operatorname{Exp})$} & $0.116^{* * *}$ & $0.086^{* * *}$ & $0.074 * * *$ & $0.023 * * *$ & $0.028 * * *$ & $0.032 * * *$ & $0.024 * * *$ \\
\hline & $(0.0025)$ & $(0.0024)$ & $(0.0024)$ & $(0.0023)$ & $(0.0023)$ & $(0.0023)$ & $(0.0019)$ \\
\hline \multirow[t]{2}{*}{ Foreign firms (For) } & $0.252 * * *$ & $0.234 * * *$ & $0.214 * * *$ & $0.179 * * *$ & $0.175^{* * *}$ & $0.151 * * *$ & $0.118^{* * *}$ \\
\hline & $(0.0039)$ & $(0.0038)$ & $(0.0038)$ & $(0.0037)$ & $(0.0036)$ & $(0.0035)$ & $(0.0023)$ \\
\hline \multirow[t]{2}{*}{ Exp*For } & $-0.200 * * *$ & $-0.136^{* * *}$ & $-0.129 * * *$ & $-0.093 * * *$ & $-0.093 * * *$ & $-0.072 * * *$ & $-0.062 * * *$ \\
\hline & $(0.0059)$ & $(0.0055)$ & $(0.0054)$ & $(0.0053)$ & $(0.0053)$ & $(0.0052)$ & $(0.0037)$ \\
\hline \multirow[t]{2}{*}{ Productivity $(L P)$} & & $0.126^{* * *}$ & $0.127 * * *$ & $0.117 * * *$ & $0.119 * * *$ & $0.117 * * *$ & $0.092 * * *$ \\
\hline & & $(0.0006)$ & $(0.0006)$ & $(0.0006)$ & $(0.0006)$ & $(0.0006)$ & $(0.0003)$ \\
\hline \multirow[t]{2}{*}{ Firm size (Size) } & & $0.045 * * *$ & $0.035 * * *$ & $0.040 * * *$ & $0.035 * * *$ & $0.032 * * *$ & $0.033 * * *$ \\
\hline & & $(0.0005)$ & $(0.0005)$ & $(0.0004)$ & $(0.0004)$ & $(0.0004)$ & $(0.0003)$ \\
\hline \multirow[t]{2}{*}{ Firm age (Age) } & & $-0.005^{* * *}$ & 0.0001 & $0.008 * * *$ & $0.008 * * *$ & $0.012 * * *$ & $0.008 * * *$ \\
\hline & & $(0.0005)$ & $(0.0005)$ & $(0.0005)$ & $(0.0005)$ & $(0.0005)$ & $(0.0004)$ \\
\hline \multirow[t]{2}{*}{ Capital intensity $(K L)$} & & $-0.005 * * *$ & $0.002 * * *$ & $0.001 * * *$ & $0.005 * * *$ & $0.003 * * *$ & $0.004 * * *$ \\
\hline & & $(0.0004)$ & $(0.0004)$ & $(0.0004)$ & $(0.0004)$ & $(0.0004)$ & $(0.0003)$ \\
\hline \multirow[t]{2}{*}{ Female share (Fem) } & & & & & & $-0.066^{* * *}$ & $-0.070 * * *$ \\
\hline & & & & & & $(0.0020)$ & $(0.0016)$ \\
\hline \multirow[t]{2}{*}{ Graduate share } & & & & & & $0.553 * * *$ & $0.410 * * *$ \\
\hline & & & & & & $(0.0282)$ & $(0.0149)$ \\
\hline \multirow[t]{2}{*}{ College share } & & & & & & $0.260 * * *$ & $0.212 * * *$ \\
\hline & & & & & & $(0.0036)$ & $(0.0024)$ \\
\hline \multirow[t]{2}{*}{ High-school share } & & & & & & $0.025 * * *$ & $0.023 * * *$ \\
\hline & & & & & & $(0.0017)$ & $(0.0013)$ \\
\hline Industry dummies & No & No & Yes & No & Yes & Yes & Yes \\
\hline Province dummies & No & No & No & Yes & Yes & Yes & Yes \\
\hline \multirow[t]{2}{*}{ Constant } & $2.031 * * *$ & $1.216^{* * *}$ & $1.081 * * *$ & $1.447 * * *$ & $1.352 * * *$ & $1.347 * * *$ & $1.474 * * *$ \\
\hline & $(0.0005)$ & $(0.0034)$ & $(0.0040)$ & $(0.0049)$ & $(0.0052)$ & $(0.0052)$ & $(0.0036)$ \\
\hline $\mathrm{N}$ & 890,154 & 890,154 & 890,154 & 890,154 & 890,154 & 890,154 & 890,154 \\
\hline Adjusted $\mathrm{R}^{2 .}$ & 0.012 & 0.131 & 0.162 & 0.222 & 0.235 & 0.244 & 0.269 \\
\hline
\end{tabular}

Note: The coefficients in Columns (1)-(6) are estimated using the OLS method. Robust standard errors are reported in parentheses. The coefficients in Column (7) are estimated using the robust regression method. *** indicates significance at the $1 \%$ level. 
In column (2), we include four control variables, namely, labour productivity, firm size, firm age and capital intensity. The value of the adjusted $\mathrm{R}^{2}$ increases substantially. The coefficients of the export dummy, foreign firm dummy and their interaction term are all different, which implies that firm characteristics account for part of the wage gap between exporting firms and non-exporting firms. Given that wage levels vary enormously across industries and regions, we introduce 28 two-digit industry dummies and 30 provincial dummies alternatively in regressions (3)-(5). The wage gap changes marginally once we control for the industrial fixed effects, while it changes dramatically after we control for the firms' locations.

Nevertheless, our conclusions drawn from regressions (1)-(5) may be spurious. An exporting firm could pay higher due to its intensive employment of skilled workers. To take this issue into consideration, we extend the specification to control for the skill composition and the share of female workers. The estimation results are reported in columns (6) and (7) in Table 2 and the main findings remain the same. The proportion of skilled labour has a significantly positive effect on wages, suggesting that more skill-intensive firms have higher average wages. The proportion of female workers is negatively associated with the average wage level. This confirms that there is a significant gender wage differential in China. Other firm characteristics, namely, the labour productivity, size, age and capital intensity, are positively related to wage levels, indicating that larger, older and more productive and capital-intensive firms offer higher wages. In column (7), we run a robust regression to handle the possible influence of outliers. ${ }^{4}$ But the results do not change. Exporters on average pay 2.4\% more than nonexporters, while foreign exporters pay $3.8 \%$ less than nonexporters.

The classification between domestic firms and foreign firms may be overly simplistic in China. As it is well known, foreign firms in China are divided into two groups, namely, those originated from Hong Kong, Macau, and Taiwan (thereafter, HMT) and those originated from western countries, mainly OECD countries (thereafter, OECD). These two groups differ enormously in terms of motivation and investment behaviour. The HMTs are concentrated in light industries particularly textile projects using labour-intensive technology, while OECD investors are more interested in the market-seeking type of investment motivated by their ability to provide differentiated products to Chinese market. Within the domestic ownership category, state-owned enterprises (thereafter, SOE) are very different from non-state owned enterprises (thereafter, Non-SOE). It is argued that SOEs enjoy higher earnings than the non-SOEs due to the government's support and protection of the former. $^{5}$

\footnotetext{
${ }^{4}$ We used the "robust regression" command "rreg" in Stata It works iteratively first by performing a regression to calculate weights based on residuals and then using these weights for further regressions until changes in the weights drop to a certain level. Hamilton (2008, p.253) states "Robust regression methods aim to achieve almost the efficiency of OLS with ideal data and substantially better than OLS efficiency in non-ideal (for example, non-normal errors) situations".

${ }^{5}$ Buckley, Wang and Clegg (2007) provided useful discussions of the different characteristics of firms with different ownership.
} 
To examine the export wage premia across different ownership categories, we divide the sampled firms into eight categories: OECD exporters and nonexporters, HMT exporters and nonexporters, SOE exporters and nonexporters, and Non-SOE exporters and nonexporters. The results from this set of regressions with the non-SOE nonexporters as the base group are reported in Table 3. It is shown that export wage premia do not exist among HMT-invested firms. HMT exporters on average pay $7 \%$ less than HMT non-exporters. This may also explain why exporters in Guangdong province generally pay less than nonexporters. Among the sampled firms, we find that $57 \%$ of the HMT-invested firms are located in Guangdong and they account for $56.6 \%$ of the exporting firms there.

\section{Table 3}

Basic wage equation: the role of ownership.

\begin{tabular}{|c|c|c|c|c|c|c|c|}
\hline & \multicolumn{7}{|c|}{ Dependent variable: $\ln ($ average wage $)$} \\
\hline & (1) & $(2)$ & (3) & (4) & $(5)$ & $(6)$ & (7) \\
\hline \multirow[t]{2}{*}{ OECD exporter } & $0.290 * * *$ & $0.271 * * *$ & $0.254 * * *$ & $0.237 * * *$ & $0.238 * * *$ & $0.230 * * *$ & $0.191 * * *$ \\
\hline & $(0.006)$ & $(0.006)$ & $(0.006)$ & $(0.006)$ & $(0.006)$ & $(0.006)$ & $(0.004)$ \\
\hline \multirow[t]{2}{*}{ OECD nonexporter } & $0.289 * * *$ & $0.263 * * *$ & $0.246^{* * *}$ & $0.232 * * *$ & $0.227 * * *$ & $0.195 * * *$ & $0.155 * * *$ \\
\hline & $(0.006)$ & $(0.006)$ & $(0.006)$ & $(0.006)$ & $(0.005)$ & $(0.005)$ & $(0.003)$ \\
\hline \multirow[t]{2}{*}{ HMT exporter } & $0.095 * * *$ & $0.141 * * *$ & $0.109 * * *$ & $0.034 * * *$ & $0.034 * * *$ & $0.039 * * *$ & $0.022 * * *$ \\
\hline & $(0.004)$ & $(0.004)$ & $(0.004)$ & $(0.004)$ & $(0.004)$ & $(0.004)$ & $(0.003)$ \\
\hline \multirow[t]{2}{*}{ HMT nonexporter } & $0.224 * * *$ & $0.221 * * *$ & $0.198 * * *$ & $0.142 * * *$ & $0.138 * * *$ & $0.122 * * *$ & $0.093 * * *$ \\
\hline & $(0.005)$ & $(0.005)$ & $(0.005)$ & $(0.005)$ & $(0.005)$ & $(0.005)$ & $(0.003)$ \\
\hline \multirow[t]{2}{*}{ SOE exporter } & $0.557 * * *$ & $0.300 * * *$ & $0.283 * * *$ & $0.305 * * *$ & $0.286 * * *$ & $0.267 * * *$ & $0.281 * * *$ \\
\hline & $(0.018)$ & $(0.015)$ & $(0.014)$ & $(0.014)$ & $(0.014)$ & $(0.013)$ & $(0.009)$ \\
\hline \multirow[t]{2}{*}{ SOE nonexporter } & $0.256^{* * *}$ & $0.152 * * *$ & $0.152 * * *$ & $0.180 * * *$ & $0.173 * * *$ & $0.150 * * *$ & $0.143^{* * *}$ \\
\hline & $(0.007)$ & $(0.006)$ & $(0.060)$ & $(0.006)$ & $(0.006)$ & $(0.006)$ & $(0.003)$ \\
\hline \multirow[t]{2}{*}{ Non-SOE exporter } & $0.099 * * *$ & $0.081 * * *$ & $0.069 * * *$ & $0.014 * * *$ & $0.020 * * *$ & $0.024 * * *$ & $0.018^{* * *}$ \\
\hline & $(0.003)$ & $(0.002)$ & $(0.002)$ & $(0.002)$ & $(0.002)$ & $(0.002)$ & $(0.002)$ \\
\hline Firm features & No & Yes & Yes & Yes & Yes & Yes & Yes \\
\hline Female and skill & No & No & No & No & No & Yes & Yes \\
\hline Industry dummies & No & No & Yes & No & Yes & Yes & Yes \\
\hline Province dummies & No & No & No & Yes & Yes & Yes & Yes \\
\hline $\mathrm{N}$ & 890,154 & 890,154 & 890,154 & 890,154 & 890,154 & 890,154 & 890,154 \\
\hline adjusted $\mathrm{R}^{2}$ & 0.018 & 0.133 & 0.164 & 0.225 & 0.238 & 0.247 & 0.274 \\
\hline
\end{tabular}

Note: Firm features include labour productivity, size, age and capital intensity; Female and skill share represent the female share of the total employees, the share of workers with graduate degrees, the share of workers with college degrees and the share of workers with high-school certificates. The coefficients in Columns (1)-(6) are estimated using the OLS method. Robust standard errors are reported in parentheses. The coefficients in Column (7) are estimated using the robust regression method. *** indicates significance at $1 \%$ level.

\subsection{Results of the quantile regressions}

The advantage of the quantile regressions over the OLS method has been well documented (Koenker and Hallock, 2001). First, quantile regression results are more robust to the outliers than the OLS ones. Second, the quantile regressions can provide parameter estimates at different quantiles. Therefore, it provides information on the variation in the effect of independent variables at different 
quantiles. It is worthy to mention that quantile regressions are not the same as the application of the OLS method to the subsets of the data produced by dividing the whole sample into different percentiles of the dependent variable. For each quantile regression, the whole sample is used with some observations being weighted more than others.

Before running our regressions we test the normality of the wage variable. The skewness and kurtosis tests of D'Agostino et al. (1990) show (at the 1 per cent level of significance) that the dependent variable is positively skewed and leptokurtic (skewness=55.41 and kurtosis=16634.11). Skewness and kurtosis tests for the natural logarithm of average wage also show statistically significant departures from normality (as the p-values of the skewness and kurtosis tests are smaller than 0.01). These results show that the distribution of the dependent variable significantly departs from normality and justify our choice of the quantile regression method.

\section{Table 4}

Results of quantile regressions.

\begin{tabular}{llllll}
\hline \multirow{5}{*}{ OECD exporter } & \multicolumn{5}{c}{ Dependent variable: ln(average wage) } \\
& $0.082^{* * *}$ & $0.155^{* * *}$ & $0.201^{* * *}$ & $0.264^{* * *}$ & Q 0.90 \\
\hline \multirow{2}{*}{ OECD nonexporter } & $(0.006)$ & $(0.004)$ & $(0.005)$ & $(0.005)$ & $(0.008)$ \\
& $0.054^{* * *}$ & $0.110^{* * *}$ & $0.169^{* * *}$ & $0.227^{* * *}$ & $0.354^{* * *}$ \\
HMT exporter & $(0.005)$ & $(0.004)$ & $(0.004)$ & $(0.004)$ & $(0.006)$ \\
& 0.001 & 0.005 & $0.019^{* * *}$ & $0.045^{* * *}$ & $0.087^{* * *}$ \\
HMT nonexporter & $(0.005)$ & $(0.004)$ & $(0.004)$ & $(0.004)$ & $(0.006)$ \\
& $0.028^{* * *}$ & $0.061^{* * *}$ & $0.096^{* * *}$ & $0.140^{* * *}$ & $0.247^{* * *}$ \\
SOE exporter & $(0.005)$ & $(0.004)$ & $(0.004)$ & $(0.004)$ & $(0.006)$ \\
& $0.096^{* * *}$ & $0.233^{* * *}$ & $0.282^{* * *}$ & $0.350^{* * *}$ & $0.400^{* * *}$ \\
SOE nonexporter & $(0.013)$ & $(0.010)$ & $(0.011)$ & $(0.012)$ & $(0.017)$ \\
& $-0.035^{* * *}$ & $0.060^{* * *}$ & $0.145^{* * *}$ & $0.235^{* * *}$ & $0.367^{* * *}$ \\
Non-SOE exporter & $(0.005)$ & $(0.004)$ & $(0.004)$ & $(0.004)$ & $(0.006)$ \\
& $0.012^{* * *}$ & $0.018^{* * *}$ & $0.022^{* * *}$ & $0.021^{* * *}$ & $0.025^{* * *}$ \\
Firm features & $(0.003)$ & $(0.002)$ & $(0.022)$ & $(0.003)$ & $(0.004)$ \\
Female and skill share & Yes & Yes & Yes & Yes & Yes \\
Industry dummies & Yes & Yes & Yes & Yes & Yes \\
Province dummies & Yes & Yes & Yes & Yes & Yes \\
Constant & $1.099^{* * *}$ & $1.361^{* * *}$ & Yes & Yes & Yes \\
& $(0.005)$ & $(0.004)$ & $(0.005)$ & $(0.005)$ & $(0.007)$ \\
N & 890,154 & 890,154 & 890,154 & 890,154 & 890,154 \\
Pseudo R ${ }^{2}$. & 0.124 & 0.121 & 0.161 & 0.152 & 0.142 \\
\hline
\end{tabular}

Note: Firm features include labour productivity, size, age and capital intensity; Female and skill share represent the female share of the total employees, the share of workers with graduate degrees, the share of workers with college degrees and the share of workers with high-school certificates. Standard errors are reported in parentheses. $* * *$ indicates significance at $1 \%$ level. 
To explore the differences in export wage premium across the groups with different ownership, we also divide the whole sample into eight groups as in Table 2, taking domestically-oriented non-SOEs as the base group. Thus the export wage premium for each group equals the difference in the coefficients of the exporter dummy and nonexporter dummy. If the coefficient of the exporter dummy is greater than that of the nonexporter dummy, it provides evidence that exporting firms pay higher wages than nonexporting firms. Otherwise, it indicates the exporters pay less. In Table 4, we report the results of quantile regressions at the following five quantiles: $0.10,0.30,0.50,0.70$ and 0.90 . The null hypothesis that the coefficients are equal across and between pairs of quantiles is rejected at the significance level of 5 per cent. It thus can be concluded that there are statistically significant differences among the estimated quantile regression parameters.

Comparing the coefficients of the exporter dummies and nonexporter dummies, we first notice that export wage premia are present across the entire conditional wage distribution among the OECD firms, SOEs and non-SOEs except for the HMT firms. Second, the wage premia of SOE exporters is relatively large but it decreases as one moves from the lowest quantile to the highest quantile of the conditional wage distribution. This means that SOEs with lower wages have higher wage premia for exporting activities. The export wage premia of SOEs are more pronounced at the lower tail of the conditional wage distribution. Third, the HMT exporters always show a wage discount ranging from 2.8 to -16.0 per cent as one moves up to the upper tail of the conditional wage distribution. Finally, it is shown that OECD exporters and non-SOE exporters always have positive wage premia but the premia remain relatively stable across quantiles varying between 1 and 5 per cent. To investigate the sensitivity of the findings observed in Tables 4, additional quantile regressions were run and we find the patterns are robust to changes in the quantiles.

\subsection{Robustness checks}

\subsubsection{Alternative measurement of variables}

In the preceding sections, we only use the average wage as the dependent variable. It is common knowledge that Chinese firms also pay employees non-wage benefits such as payment for unemployment insurances, medical care insurance, old-age pension funds and housing subsidies. We hence use the total income, measured as the sum of basic wage and non-wage benefits, as the dependent variable in this section.

Besides using the alternative measurement of the dependent variable, we also consider using different measurement of exporting activity according to their export intensities. We have noticed that about half of the exporting firms shipped all of their outputs overseas. It is expected to see some differences in wages between those exported partly and fully. Therefore, we divide the exporting firms into two categories: 'Full exporters' with 100 per cent export intensity (the ratio of the exports 
over total sales) and 'Partial exporters' with export intensity less than 100 per cent, and then rerun the regressions using the sub-samples.

The results in column (1) of Table 5 show that the previous findings are robust to the alternative measurement of the dependent variable. Chinese workers working in exporting firms with the exception of HMT firms on average have higher income than those working in nonexporting firms. However, when we reclassify the exporters according to their export intensity, we find that firms selling in both domestic and foreign markets pay higher average wages than non-exporting firms. But, if the exporters are restricted to those selling all their output abroad, the export wage premium marginally exists among non-SOEs only.

Table 5

Robustness results: alternative measurement of variables.

\begin{tabular}{|c|c|c|c|c|c|}
\hline & \multicolumn{3}{|c|}{ Ln(income) } & \multicolumn{2}{|c|}{ Ln(wage) } \\
\hline & $\begin{array}{l}\text { Whole } \\
\text { sample }\end{array}$ & $\begin{array}{l}\text { Partial } \\
\text { exporter }\end{array}$ & $\begin{array}{l}\text { Full } \\
\text { exporter }\end{array}$ & $\begin{array}{l}\text { Partial } \\
\text { exporter }\end{array}$ & $\begin{array}{l}\text { Full } \\
\text { exporter }\end{array}$ \\
\hline \multirow[t]{2}{*}{ OECD exporter } & $0.211 * * *$ & $0.269 * * *$ & $0.170 * * *$ & $0.245 * * *$ & $0.154 * * *$ \\
\hline & $(0.004)$ & $(0.006)$ & $(0.005)$ & $(0.006)$ & $(0.005)$ \\
\hline \multirow[t]{2}{*}{ OECD nonexporter } & $0.170 * * *$ & $0.170 * * *$ & $0.171 * * *$ & $0.155^{* * *}$ & $0.155^{* * *}$ \\
\hline & $(0.003)$ & $(0.003)$ & $(0.003)$ & $(0.003)$ & $(0.003)$ \\
\hline \multirow[t]{2}{*}{ HMT exporter } & $0.040 * * *$ & $0.136 * * *$ & 0.001 & $0.122 * * *$ & $-0.018 * * *$ \\
\hline & $(0.003)$ & $(0.006)$ & $(0.004)$ & $(0.006)$ & $(0.004)$ \\
\hline \multirow[t]{2}{*}{ HMT nonexporter } & $0.103 * * *$ & $0.101 * * *$ & $0.102 * * *$ & $0.091 * * *$ & $0.092 * * *$ \\
\hline & $(0.003)$ & $(0.003)$ & $(0.003)$ & $(0.003)$ & $(0.003)$ \\
\hline \multirow[t]{2}{*}{ SOE exporter } & $0.309 * * *$ & $0.330 * * *$ & -0.032 & $0.301 * * *$ & -0.013 \\
\hline & $(0.009)$ & $(0.009)$ & $(0.035)$ & $(0.009)$ & $(0.034)$ \\
\hline \multirow[t]{2}{*}{ SOE nonexporter } & $0.144 * * *$ & $0.143 * * *$ & $0.146 * * *$ & $0.143 * * *$ & $0.146^{* * *}$ \\
\hline & $(0.003)$ & $(0.003)$ & $(0.003)$ & $(0.003)$ & $(0.003)$ \\
\hline \multirow[t]{2}{*}{ Non-SOE exporter } & $0.021 * * *$ & $0.025 * * *$ & $0.012 * * *$ & $0.021 * * *$ & $0.012 * * *$ \\
\hline & $(0.002)$ & $(0.003)$ & $(0.003)$ & $(0.003)$ & $(0.003)$ \\
\hline Firm features & Yes & Yes & Yes & Yes & Yes \\
\hline Female and skill share & Yes & Yes & Yes & Yes & Yes \\
\hline Industry dummies & Yes & Yes & Yes & Yes & Yes \\
\hline Province dummies & Yes & Yes & Yes & Yes & Yes \\
\hline \multirow[t]{2}{*}{ Constant } & $1.432 * * *$ & $1.435 * * *$ & $1.436 * * *$ & $1.492 * * *$ & $1.492 * * *$ \\
\hline & $(0.004)$ & $(0.004)$ & $(0.004)$ & $(0.004)$ & $(0.004)$ \\
\hline $\mathrm{N}$ & 890,154 & 864,977 & 866,759 & 864,977 & 866,759 \\
\hline $\mathrm{R}^{2}$ & 0.281 & 0.283 & 0.275 & 0.276 & 0.268 \\
\hline
\end{tabular}

Note: Firm features include labour productivity, size, age and capital intensity. Female and skill share represent the female share of the total employees, the share of workers with graduate degrees, the share of workers with college degrees and the share of workers with high-school certificates. All the coefficients are estimated using the robust regression method. Standard errors are reported in parentheses. *** indicates significance at $1 \%$ level. 


\subsubsection{Location-related export wage premium}

Given the vastness of the Chinese territory, it seems unlikely that exporting firms located in the coastal provinces behave the same as those located in the interior regions. ${ }^{6}$ In fact, the coastal regions have been the main source of exports and main recipients of FDI due to their convenient location, better infrastructure and superior business environment. Among the coastal regions, the geographic distribution of trade and FDI has also been highly uneven. Thus, in our second robustness check, we compare the export wage premium in different regions. The full sample is first split into the coastal region and interior region. Then the coastal region is further divided into Guangdong province and other coastal provinces (non-Guangdong). The estimation results are reported in Table 6.

\section{Table 6}

Robustness results: coastal vs. interior region.

\begin{tabular}{|c|c|c|c|c|}
\hline & \multicolumn{4}{|c|}{ Dependent variable: $\ln ($ average wage) } \\
\hline & $\begin{array}{l}\text { Coastal region } \\
\text { (1) }\end{array}$ & $\begin{array}{l}\text { Interior region } \\
\text { (2) }\end{array}$ & $\begin{array}{l}\text { Guangdong } \\
\text { (3) }\end{array}$ & $\begin{array}{l}\text { Non-Guangdong } \\
\text { (4) }\end{array}$ \\
\hline \multirow[t]{2}{*}{ OECD exp } & $0.190 * * *$ & $0.129 * * *$ & $0.046 * * *$ & $0.197 * * *$ \\
\hline & $(0.004)$ & $(0.017)$ & $(0.009)$ & $(0.005)$ \\
\hline \multirow[t]{2}{*}{ OECD nonexp } & $0.161 * * *$ & $0.092 * * *$ & $0.070 * * *$ & $0.165^{* * *}$ \\
\hline & $(0.003)$ & $(0.009)$ & $(0.009)$ & $(0.004)$ \\
\hline \multirow[t]{2}{*}{ HMT exp } & $0.011 * * *$ & $0.064 * * *$ & $-0.029 * * *$ & $0.199 * * *$ \\
\hline & $(0.003)$ & $(0.021)$ & $(0.004)$ & $(0.007)$ \\
\hline \multirow[t]{2}{*}{ HMT nonexp } & $0.093 * * *$ & $0.056^{* * *}$ & $0.029 * * *$ & $0.175^{* * *}$ \\
\hline & $(0.003)$ & $(0.010)$ & $(0.006)$ & $(0.005)$ \\
\hline \multirow[t]{2}{*}{ SOE exp } & $0.302 * * *$ & $0.265 * * *$ & $0.456 * * *$ & $0.300 * * *$ \\
\hline & $(0.011)$ & $(0.014)$ & $(0.029)$ & $(0.013)$ \\
\hline \multirow[t]{2}{*}{ SOE nonexp } & $0.211^{* * *}$ & $0.099 * * *$ & $0.219 * * *$ & $0.219 * * *$ \\
\hline & $(0.015)$ & $(0.005)$ & $(0.014)$ & $(0.005)$ \\
\hline \multirow[t]{2}{*}{ Non-SOE exp } & $0.015^{* * *}$ & $0.029 * * *$ & $-0.018 * * *$ & $0.055^{* * *}$ \\
\hline & $(0.002)$ & $(0.005)$ & $(0.005)$ & $(0.002)$ \\
\hline Firm features & Yes & Yes & Yes & Yes \\
\hline Female and skill & Yes & Yes & Yes & Yes \\
\hline Industry dummies & Yes & Yes & Yes & Yes \\
\hline Province dummies & Yes & Yes & No & Yes \\
\hline \multirow[t]{2}{*}{ Constant } & $1.466^{* * *}$ & $1.197 * * *$ & $1.486^{* * *}$ & $1.298 * * *$ \\
\hline & $(0.004)$ & $(0.011)$ & $(0.011)$ & $(0.004)$ \\
\hline $\mathrm{N}$ & 609,383 & 280,771 & 86,367 & 523,016 \\
\hline
\end{tabular}

Note: Firm features include labour productivity, size, age and capital intensity. Female and skill represented the female share of the total employees, the share of workers with graduate degrees, the share of workers with college degrees and the share of workers with high-school certificates. The benchmark category is the non-state-owned enterprises (Non-SOEs) which are not exporters. Numbers in parentheses are standard errors. The estimates are from the robust regressions. $*, * *$ and $* * *$ represent statistical significance at $10 \%$, $5 \%$ and $1 \%$ levels, respectively.

\footnotetext{
${ }^{6}$ The coastal region includes Beijing, Fujian, Guangdong, Hainan, Hebei, Jiangsu, Liaoning, Shandong, Shanghai, Tianjin and Zhejiang. The interior region includes all other provinces.
} 
The results for the firms located in the coastal region are similar to those from the baseline regressions. It is shown that exporting firms except for the HMT exporters pay higher average wages than nonexporting firms. However, we find that the wage premium of HMT exporters in the interior region also becomes positive. For the exporting firms producing in Guangdong province, however, only SOEs show positive export wage premia and other three types of firms show a negative wage premium. Meanwhile, we find that the exporting firms in "other coastal" provinces (non-Guangdong) show a similar pattern as those located in the interior region and tend to pay higher wages than nonexporting firms.

Guangdong is different from the rest of China perhaps due to its unique position in China's foreign trade and its mode of exporting. In the last two decades, this province contributed to over a third of China's total exports. However, more than two thirds of the provinces' exports are processed goods from textiles to machinery, and the profit margins are very small. Another characteristic is that exporting was mainly carried out by multinationals through the processing trade. In 2004, the processing trade generated 76 per cent of the province's exports and it also accounted for 44.4 per cent of the country's processing trade exports. Compared with those focusing on the domestic market, exporting firms would take full advantage of the low cost and abundant labour resources in China and hence pay lower wages.

\subsubsection{Industry-specific export wage premium}

In models with perfect factor mobility, wages equalize across sectors and there should thus be an aggregate export premium affecting all the workers in the labor market. With imperfect factor mobility of labor, wage equalization does not occur, and export premia at the industry level can result in equilibrium (Brambilla et al., 2010). To investigate this scenario, we expand our previous analysis to estimate export premia by sector.

We estimate 29 premia for each 2-digit industry in Chinese manufacturing sector. A positive export wage premium is observed in twenty-five industries. However, there are significant differences in the export wage premia according to Table 7. The highest wage premia (over 10\%) are found in the petroleum processing and tobacco industries, which are dominated by the SOEs. Table 7 also shows that the premia are smaller in traditional labor-intensive industries. To gain more insights into this issue, sector-specific export wage premia are plotted against the average capital intensity in each sector and the chart shows clearly a positive relationship between the two (Fig. 4). 


\section{Table 7}

Robustness results: industry-specific export wage premium.

\begin{tabular}{|c|c|c|c|c|c|}
\hline \multicolumn{2}{|c|}{ 2-digit industry } & \multirow{2}{*}{$\begin{array}{l}\text { Number of firms } \\
50,026\end{array}$} & \multirow{2}{*}{$\begin{array}{l}\text { Percent }(\%) \\
5.62\end{array}$} & \multirow{2}{*}{$\frac{\text { Coefficient }}{0.050 * * *}$} & \multirow{2}{*}{$\begin{array}{l}\text { Std. Err } \\
0.009\end{array}$} \\
\hline 13 & Food Processing & & & & \\
\hline 14 & Food Production & 21,003 & 2.36 & $0.058 * * *$ & 0.012 \\
\hline 15 & Beverage & 19,403 & 2.18 & $0.066^{* * *}$ & 0.018 \\
\hline 16 & Tobacco & 172 & 0.02 & $0.128 * * *$ & 0.126 \\
\hline 17 & Textile & 52,768 & 5.93 & $0.052 * * *$ & 0.005 \\
\hline 18 & Garments & 30,795 & 3.46 & $0.039 * * *$ & 0.005 \\
\hline 19 & Leather & 13,939 & 1.57 & $0.022 * * *$ & 0.007 \\
\hline 20 & Timber Processing & 31,437 & 3.53 & $0.057 * * *$ & 0.008 \\
\hline 21 & Furniture & 18,411 & 2.07 & $0.047 * * *$ & 0.010 \\
\hline 22 & Papermaking & 29,204 & 3.28 & $0.023 * * *$ & 0.011 \\
\hline 23 & Printing & 34,303 & 3.85 & -0.003 & 0.015 \\
\hline 24 & Cultural & 9,804 & 1.1 & $0.026^{* * *}$ & 0.008 \\
\hline 25 & Petroleum Processing & 4,072 & 0.46 & $0.136 * * *$ & 0.047 \\
\hline 26 & Raw Chemical & 49,779 & 5.59 & $0.061 * * *$ & 0.061 \\
\hline 27 & Medical & 5,237 & 0.59 & $0.078 * * *$ & 0.024 \\
\hline 28 & Chemical Fibre & 1,630 & 0.18 & $0.096 * * *$ & 0.040 \\
\hline 29 & Rubber & 10,882 & 1.22 & $0.053 * * *$ & 0.014 \\
\hline 30 & Plastic & 51,541 & 5.79 & $0.018 * * *$ & 0.006 \\
\hline 31 & Non-metal Products & 125,898 & 14.14 & $0.071 * * *$ & 0.007 \\
\hline 32 & Pressing Ferrous & 11,325 & 1.27 & $0.103 * * *$ & 0.024 \\
\hline 33 & Pressing of Nonferrous & 8,671 & 0.97 & $0.035 * * *$ & 0.019 \\
\hline 34 & Metal Products & 59,041 & 6.63 & 0.003 & 0.006 \\
\hline 35 & Ordinary Machinery & 84,654 & 9.51 & $0.053 * * *$ & 0.006 \\
\hline 36 & Special Equipment & 39,274 & 4.41 & $0.073 * * *$ & 0.009 \\
\hline 37 & Transport Equipment & 37,858 & 4.25 & $0.079 * * *$ & 0.010 \\
\hline 39 & Electric Machinery & 38,365 & 4.31 & $0.024 * * *$ & 0.009 \\
\hline 40 & Electric Equipment & 15,403 & 1.73 & -0.015 & 0.009 \\
\hline 41 & Electronic and Telecom & 11,253 & 1.26 & -0.007 & 0.012 \\
\hline 42 & Instruments & 24,006 & 2.7 & $0.009 *$ & 0.006 \\
\hline Tot: & & 890,154 & 100 & & \\
\hline
\end{tabular}

Note: The coefficient denotes the coefficient of the export dummy obtained from the regression of log wage against the export dummy and firm features for the sample of each sector. Firm features include labour productivity, size, age and capital intensity. Female and skill represent the female share of the total employees, the share of workers with graduate degrees, the share of workers with college degrees and the share of workers with high-school certificates. Region dummies are also included. The estimates are from the robust regressions. $*, * *$ and $* * *$ represent statistical significance at $10 \%, 5 \%$ and $1 \%$ levels, respectively. 


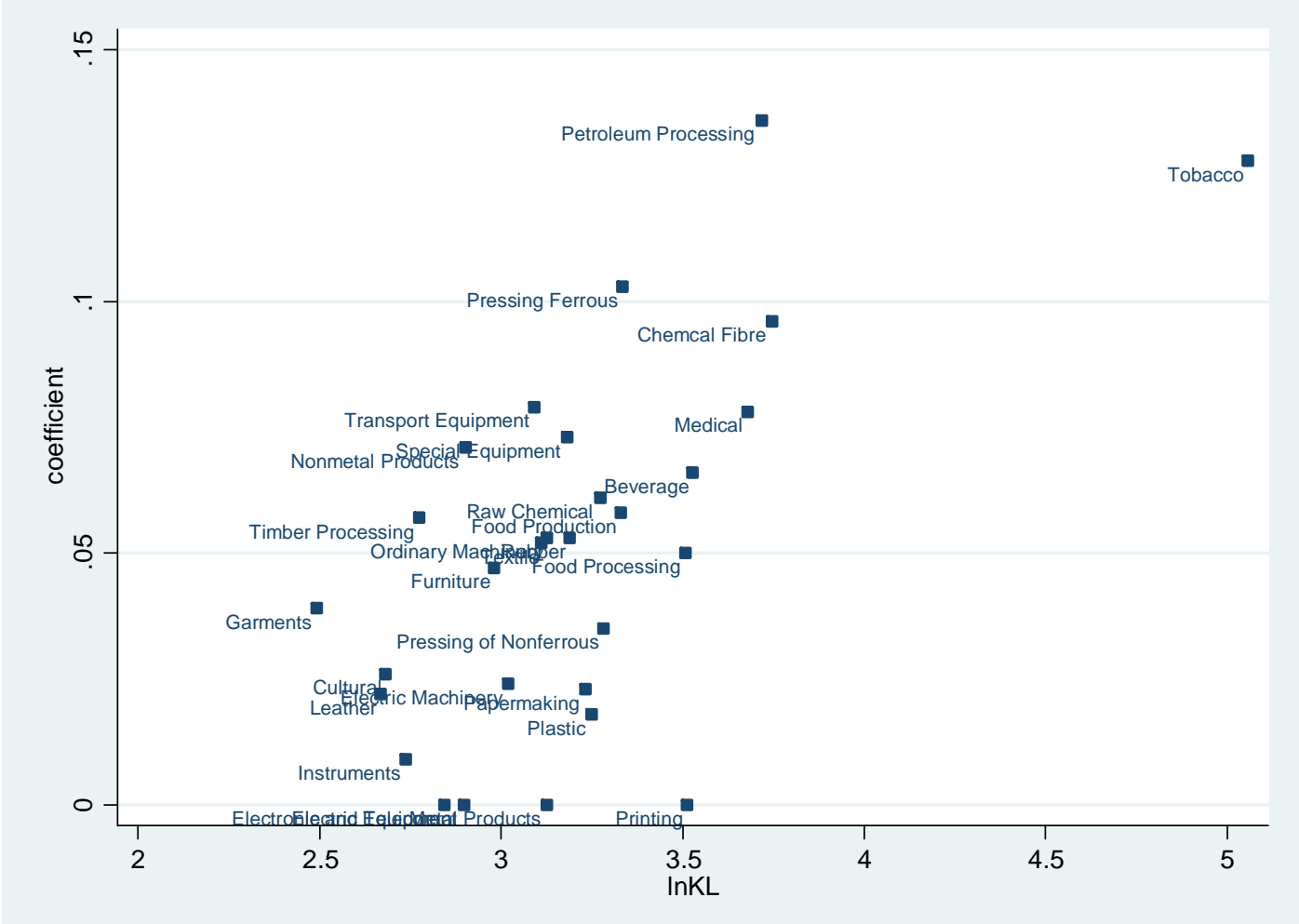

Fig.4. Industry-specific export wage premium against capital intensity.

\subsubsection{Export wage premium: the results of matching estimator}

The literature on the matching methods is vast and growing. In this sub-section, we apply the Abadie-Imbens bias-corrected matching estimator to conduct a robustness check. The advantage of the matching methods is that they can eliminate sample selection biases by formally controlling for the non-random selection problem and avoid the specification of the functional form because they are nonparametric techniques (Abadie et al., 2004). In this paper, we define the exporting activity as "treatment", the exporting firms as the "treatment group" and the nonexporting firms as the "control group". ${ }^{7}$ However, we cannot observe both outcomes for the same individual with and without treatment at the same time. The matching approach is one possible way to find the control group, which helps to tackle this selection problem. Its basic idea is to find in a large group of nonparticipants those individuals who are similar to the participants in all relevant pre-treatment characteristics.

\footnotetext{
${ }^{7}$ All analyses are implemented by the use of the nnmatch module in STATA (Abadie et al, 2004). This programme estimates the average treatment effects either for the overall sample or for the subsample of treated or control units using nearest neighbour matching estimators.
} 


\section{Table 8}

Robustness results: matching estimator.

\begin{tabular}{|c|c|c|c|c|}
\hline \multirow[b]{2}{*}{$\begin{array}{l}\text { Provincial code } \\
\text { and name }\end{array}$} & \multicolumn{4}{|c|}{ Dependent variable: $\ln ($ average wage) } \\
\hline & $\begin{array}{c}\text { OECD } \\
\text { exporters } \\
(1) \\
\end{array}$ & $\begin{array}{c}\text { HMT } \\
\text { exporters } \\
(2) \\
\end{array}$ & $\begin{array}{c}\text { SOE } \\
\text { exporters } \\
(3) \\
\end{array}$ & $\begin{array}{c}\text { Non-SOE } \\
\text { exporters } \\
(4)\end{array}$ \\
\hline 11.Beijing & 0.038 & 0.005 & 0.148 & 0.008 \\
\hline 12.Tianjin & $0.118^{*}$ & 0.182 & 0.129 & -0.035 \\
\hline 13.Hebei & $0.152 * * *$ & -0.093 & 0.106 & $0.032 * *$ \\
\hline 14.Shanxi & -0.062 & -0.255 & 0.129 & $0.153 * * *$ \\
\hline 15.Inner Mongolia & -0.117 & 0.280 & 0.413 & -0.062 \\
\hline 21.Liaoning & 0.164 & -0.035 & $0.148^{*}$ & $0.067 * * *$ \\
\hline 22.Jilin & 0.032 & -0.066 & $0.202 *$ & $0.100 * *$ \\
\hline 23.Heilongjiang & -0.222 & 0.293 & 0.084 & $0.111^{* *}$ \\
\hline 31.Shanghai & $0.089 * * *$ & 0.051 & 0.031 & $0.043 * * *$ \\
\hline 32.Jiangsu & $0.094 * * *$ & $0.042 * *$ & $0.151^{* *}$ & $0.027 * * *$ \\
\hline 33.Zhejiang & $0.062 * * *$ & $0.068 * * *$ & 0.038 & $0.008 * *$ \\
\hline 34.Anhui & 0.064 & 0.152 & 0.119 & 0.012 \\
\hline 35.Fujian & $0.055^{*}$ & $0.049 * *$ & -0.050 & $0.020 * *$ \\
\hline 36.Jiangxi & 0.119 & 0.046 & 0.104 & $0.064 * * *$ \\
\hline 37.Shangdong & $0.074 * * *$ & 0.041 & 0.063 & $0.054 * * *$ \\
\hline 41.Henan & -0.139 & -0.025 & 0.084 & -0.005 \\
\hline 42.Hubei & -0.168 & 0.058 & 0.061 & $0.096 * * *$ \\
\hline 43.Hunan & 0.249 & -0.117 & 0.039 & 0.019 \\
\hline 44.Guangdong & 0.0001 & $-0.095 * * *$ & 0.058 & $-0.021 * * *$ \\
\hline 45.Guangxi & -0.094 & $0.181^{*}$ & -0.47 & 0.007 \\
\hline 46.Hainan & 0.449 & -0.156 & $0.939 *$ & -0.077 \\
\hline 50.Chongqing & $0.306^{*}$ & 0.186 & 0.107 & -0.026 \\
\hline 51.Sichuan & 0.192 & 0.048 & -0.007 & 0.043 \\
\hline 52.Guizhou & $0.494 * * *$ & 0.272 & 0.091 & -0.023 \\
\hline 53.Yunnan & 0.089 & -0.051 & 0.101 & 0.017 \\
\hline 54.Tibet & $0.095 * * *$ & N.A. & N.A. & N.A. \\
\hline 61.Shaanxi & 0.079 & N.A. & 0.144 & 0.026 \\
\hline 62.Gansu & 0.253 & 0.371 & 0.303 & -0.037 \\
\hline 63.Qinghai & N.A. & N.A. & N.A. & 0.350 \\
\hline 64.Ningxia & $0.601 * * *$ & N.A. & 0.055 & 0.085 \\
\hline 65.Xinjiang & N.A. & N.A. & 0.298 & -0.054 \\
\hline
\end{tabular}

Note: The matching variables include labour productivity, firm size, firm age, capital-labour ratio, female share, graduate share, college share, and high-school share. The number of matches is two. ***,** and * denote the significance level at $1 \%, 5 \%$ and $10 \%$, respectively.

Given the strong influence of firms' location on the wage level, we match exporters with nonexporters using observed firm characteristics within each province. The average treatment effects of exporting on the average wage for each province are reported in Table 8 and also illustrated in Figure 5. The figure shows that the wage premia of OECD exporters exists in four coastal provinces (i.e. Hebei, Shandong, Jiangsu and Zhejiang) and three ethnic minority regions (i.e. Tibet, Ningxia 
and Guizhou). Figure 5 illustrates the existence of a wage premium for HMT exporters. We can find that HMT exporters in Jiangsu, Zhejiang and Fujian are more like to pay higher wages than their nonexporting counterparts, while those producing in Guangdong province offer lower wages to workers. For state-owned enterprises, a positive export wage premium exists only in Jiangsu province. It may suggest that exporting activity does not affect the wage level of SOEs. Non-SOE exporters located in east and northeast China pay more to workers than nonexporters. This is however not true in Guangdong province. Once again we reckon that this regional variation may be due to the different mode of exports adopted by firms in each region with different ownership.
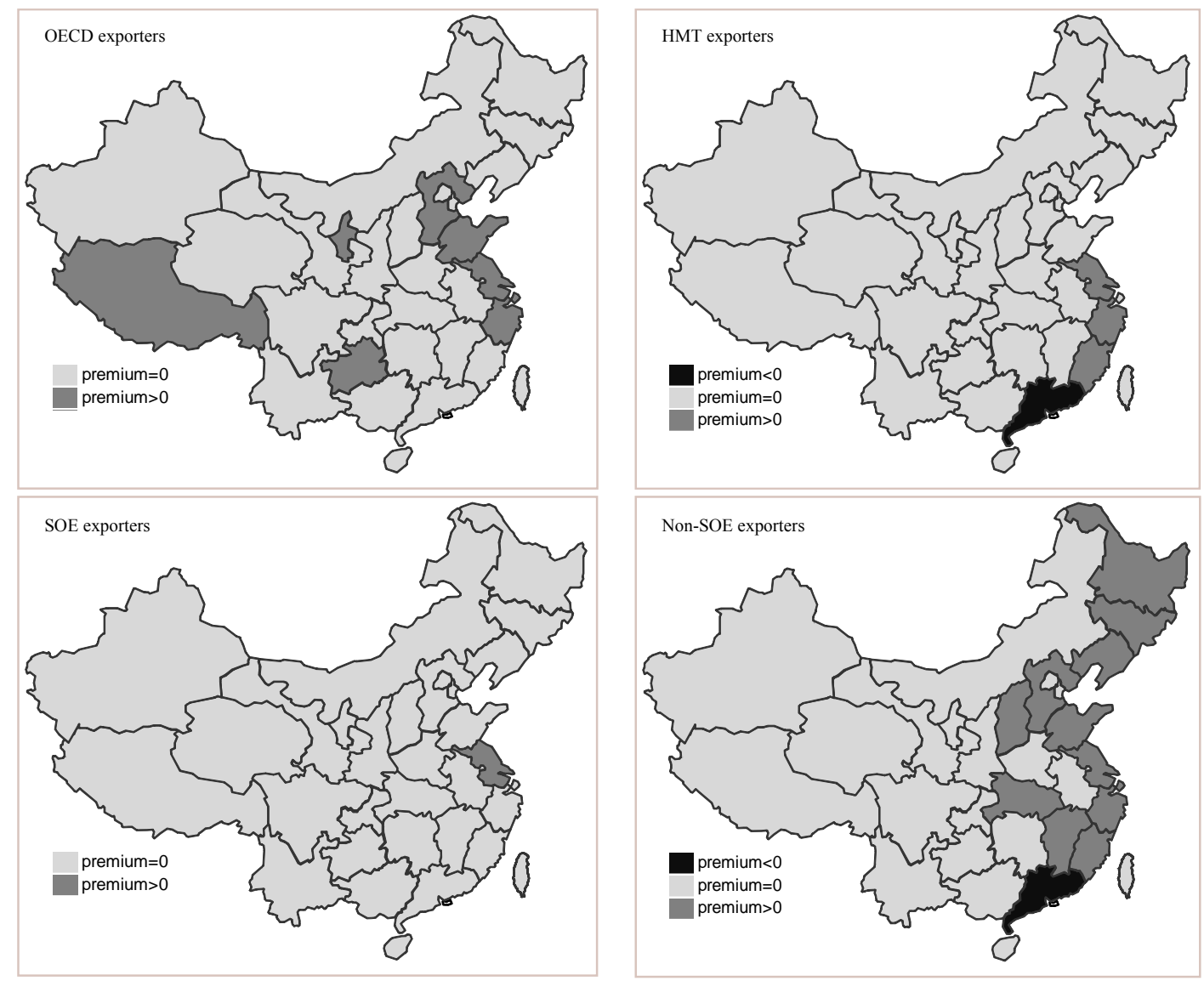

Fig.5. Export wage premium for firms with different ownership.

\section{Conclusion}

Using the firm-level census data of Chinese manufacturing industries in 2004, this paper examines the wage premium of exporting activity. In addition to using robust regressions, we also employ quantile regressions and non-parametric matching estimators. We carefully consider the role of firms' ownership, export intensity and location in determining the export wage premium. Our main empirical results may be summarized as follows. First, exporting firms except for those from Hong Kong, 
Macau and Taiwan (HMT) are more likely to pay higher average wages than their nonexporting counterparts in general, although the size of the wage gap varies according to the distribution of wages as demonstrated by the results of quantile regressions. Second, the wage premia of exporters are more likely to be associated with firms that supply both foreign and domestic markets, while the firms that shipped all their products abroad tend to pay lower. Third, exporting firms located in east China are more likely to offer a wage premium while those producing in Guangdong tend to offer lower wages than nonexporters. Among all the cases, workers in Jiangsu province are better positioned as all exporting firms operating there pay higher average wages than nonexporting firms.

Overall, our results show that the export wage premium is not a prevailing phenomenon in China. This may imply that the relationship between globalization and wage inequality within a country is far more complex. The benefit of globalization is unequally distributed among firms and across regions, which would inevitably cause wage inequality both between and within regions. We note that for decades Chinese government has been promoting FDI inflows and exports to stimulate economic growth. However, the distributional effect of trade liberalization might not be positive.

This study has a number of limitations which represent opportunities for further research. The first one is related to the cross-sectional nature of the study which relies on data of one single year (2004). It is thus impossible to discuss the direction of causality between wages and exporting decision. We do not know whether exporters pay higher wages because they are exporters or they paid higher wages before they started exporting. If data are available in the future, a longitudinal approach should be adopted so that the time dimension and dynamics of export wage premium could be considered. Second, due to the limited scope of the data, we can only discuss wage premium at the firm level (average wage premium). Further work is needed to investigate wage gaps between workers in different sectors, namely, the exporting and non-exporting sectors. 


\section{References}

Abadie, A., Drukker, D., Herr, J.L., \&Imbens, G.W. (2004). Implementing matching estimators for average treatment effects in Stata. The Stata Journal, 4(3), 290-311.

Akerlof, G.A., \&Yellen, J.L. (1990). The fair wage-effort hypothesis and unemployment. Quarterly Journal of Economics, 105(2), 255-283.

Alvarez, R., \&López, R.A. (2005). Exporting and performance: evidence from Chilean plants. Canadian Journal of Economics, 38(4), 1384-1400.

Arellano, M. \&Bond, S. (1991). Some tests of specification for panel data: Monte Carlo evidence and an application to employment equations. Review of Economic Studies, 58(2), 277-297.

Bao, Q. (2011). Does firms' export decision cause higher wage? Evidence from China's manufacturing firm level data. Economic Research Journal (Jingji Yanjiu) (forthcoming).

Baumgarten, D. (2010). Exporters and the rise in wage inequality-Evidence from German linked employeremployee Data. Ruhr Economic Papers No.217, RWI and Ruhr Graduate School in Economics.

Bernard, A.B., Eaton, J., Jensen, J.B. \& Kortum, S.S. (2003). Plants and productivity in international trade. American Economic Review, 93(4), 1268-1290.

Bernard, A.B. \&Jensen, J.B. (1997). Exporters, skill upgrading, and the wage gap. Journal of International Economics, 42(1-2), 3-31.

Brambilla, I., Carneiro, R.D., Lederman, D. \&Porto, G. (2010). Skills, exports, and the wages of five million Latin American workers. NBER working paper, No.15996.

Breau, S. \&Rigby, D.L. (2006). Is there really an export wage premium? A case study of Los Angeles using matched employee-employer data. International Regional Science Review, 29(3), 297-310.

Buckley, P.J., Wang, C. \&Clegg, J. (2007). The impact of foreign ownership, local ownership and industry characteristics on spillover benefits from foreign direct investment in China. International Business Review, $16(2), 142-158$.

Chen, Z., Ge, Y. \&Lai, H. (2011). Foreign direct investment and wage inequality: Evidence from China. World Development, 39(8), 1322-1332.

Choi, K.-S. \&Jeong, J. (2007). Does unmeasured ability explain the wage premium associated with technological change? Quantile regression analysis. Applied Economics, 39(9), 1163-1171.

D'Agostino, R.B., Belanger, A. \&D'Agostino Jr., R.B. (1990). A suggestion for using powerful and informative tests of normality. The American Statistician, 44(4), 316-321.

Davis, D.R. \&Harrigan, J. (2007). Good jobs, bad jobs, and trade liberalization. NBER working paper, No.13139.

Egger, H. \&Kreickemeier, U. (2009). Firm heterogeneity and the labour market effects of trade liberalization. International Economic Review, 50(1), 187-216.

Goldberg, P.K. \&Pavcnik, N. (2007). Distributional effects of globalization in developing countries. Journal of Economic Literature, 45(1), 39-82.

Greenaway, D. \&Yu, Z. (2004). Firm-level interactions between exporting and productivity: industry-specific evidence. Review of World Economics, 140(3), 376-392.

Hamilton, L.C. (2008). Statistics with Stata: Updated for Version 10. Belmont(CA): Thomson Brooks/Cole.

Hansson, P. \&Lundin, N.N. (2004). Exports as an indicator on or promoter of successful Swedish manufacturing firms in the 1990s. Review of World Economics, 140, 415-445.

Helpman, E., Itskhoki, O. \&Redding, S. (2010). Inequality and unemployment in a global economy. Econometrica, 78(4), 1239-1283.

Koenker, R. \&Bassett, G. (1978). Regression quantiles. Econometrica, 46(1), 33-50.

Koenker, R. \& Hallock, K.F. (2001). Quantile regression. Journal of Economic Perspectives, 15(4), 143-156.

Lipsey, R.E. \&Sjoholm, F. (2003). Foreign firms and Indonesian manufacturing wages: An analysis with panel data. NBER working paper, No.9417.

Melitz, M. (2003). The impact of trade on intra-industry reallocations and aggregate industry productivity. Econometrica, 71(6), 1695-1725.

Munch, J.R. \&Skaksen, J.R. (2008). Human capital and wages in exporting firms. Journal of International Economics, 75(2), 363-372. 
OECD (2010). Growth, employment and inequality in Brazil, China, India and South Africa: An overview. OECD, Paris.

Schank, T., Schnabel, C. \&Wagner, J. (2007). Do exporters really pay higher wages? First evidence from German linked employer-employee data. Journal of International Economics, 72(1), 52-74.

Shapiro, C. \&Stiglitz, J.E. (1984). Equilibrium unemployment as a worker discipline device. American Economic Review, 74(3), 433-444.

Tsou, M.-W., Liu, J.-T. \&Huang, C.J. (2006). Export activity, firm size and wage structure: Evidence from Taiwanese manufacturing firms. Asian Economic Journal, 20(4), 333-354.

Van Biesebroeck, J. (2005). Exporting raises productivity in sub-Saharan African manufacturing plants. Journal of International Economics, 67(2), 373-391.

Verhoogen, E.A. (2008). Trade, quality upgrading, and wage inequality in the Mexican manufacturing sector. Quarterly Journal of Economics, 132(2), 489-530.

Wood, A. (2002). Globalization and wage inequalities: A Synthesis of three theories. Review of World Economics, 138(1), 54-82.

Wooldridge, J.M. (2000). Introductory Econometrics: A Modern Approach. South-Western College Publishing.

Xu, B. \& Li, W. (2008). Trade, technology, and China's rising skill demand. Economics of Transition, 16(1), 5984.

Yeaple, S.R. (2005). A simple model of firm heterogeneity, international trade, and wages. Journal of International Economics, 65(1), 1-20.

Zhao, Y. (2001). Foreign direct investment and relative wages: The case of China. China Economic Review, $12(1), 40-57$.

\section{Acknowledgement}

We acknowledge generous financial support from the China Scholarship Council (CSC), the Business School of the University of Western Australia (UWA) and the Australian Research Council (ARC). We also thank the participants of the ACESA2011 international conference (Perth), the 2011 TED conference (Fudan), the economics departmental seminars in the University of Adelaide and Hong Kong Baptist University and Guanghua Wan for helpful comments and suggestions.

\section{About the authors}

Dahai Fu is a Ph.D. candidate in economics of Business School, The University of Western Australia, Australia. In 2008, he was offered a joint scholarship by the China Scholarship Council and the Business School of the University of Western Australia.

Yanrui Wu is Professor of Economics, Business School, The University of Western Australia, Australia. His research interests include the Chinese and Asian economies, productivity analysis, economic growth, resource and environmental economics. He has published extensively in these fields. 
ECONOMICS DISCUSSION PAPERS

2009

\begin{tabular}{|c|c|c|}
\hline $\begin{array}{l}\text { DP } \\
\text { NUMBER }\end{array}$ & AUTHORS & TITLE \\
\hline 09.01 & Le, A.T. & $\begin{array}{l}\text { ENTRY INTO UNIVERSITY: ARE THE CHILDREN OF } \\
\text { IMMIGRANTS DISADVANTAGED? }\end{array}$ \\
\hline 09.02 & Wu, Y. & CHINA'S CAPITAL STOCK SERIES BY REGION AND SECTOR \\
\hline 09.03 & Chen, M.H. & $\begin{array}{l}\text { UNDERSTANDING WORLD COMMODITY PRICES RETURNS, } \\
\text { VOLATILITY AND DIVERSIFACATION }\end{array}$ \\
\hline 09.04 & Velagic, R. & UWA DISCUSSION PAPERS IN ECONOMICS: THE FIRST 650 \\
\hline 09.05 & McLure, $\mathrm{M}$. & $\begin{array}{l}\text { ROYALTIES FOR REGIONS: ACCOUNTABILITY AND } \\
\text { SUSTAINABILITY }\end{array}$ \\
\hline 09.06 & Chen, A. and Groenewold, N. & $\begin{array}{l}\text { REDUCING REGIONAL DISPARITIES IN CHINA: AN } \\
\text { EVALUATION OF ALTERNATIVE POLICIES }\end{array}$ \\
\hline 09.07 & Groenewold, N. and Hagger, A. & $\begin{array}{l}\text { THE REGIONAL ECONOMIC EFFECTS OF IMMIGRATION: } \\
\text { SIMULATION RESULTS FROM A SMALL CGE MODEL. }\end{array}$ \\
\hline 09.08 & Clements, K. and Chen, D. & AFFLUENCE AND FOOD: SIMPLE WAY TO INFER INCOMES \\
\hline 09.09 & Clements, K. and Maesepp, M. & A SELF-REFLECTIVE INVERSE DEMAND SYSTEM \\
\hline 09.10 & Jones, C. & $\begin{array}{l}\text { MEASURING WESTERN AUSTRALIAN HOUSE PRICES: } \\
\text { METHODS AND IMPLICATIONS }\end{array}$ \\
\hline 09.11 & Siddique, M.A.B. & $\begin{array}{l}\text { WESTERN AUSTRALIA-JAPAN MINING CO-OPERATION: AN } \\
\text { HISTORICAL OVERVIEW }\end{array}$ \\
\hline 09.12 & Weber, E.J. & $\begin{array}{l}\text { PRE-INDUSTRIAL BIMETALLISM: THE INDEX COIN } \\
\text { HYPTHESIS }\end{array}$ \\
\hline 09.13 & McLure, M. & $\begin{array}{l}\text { PARETO AND PIGOU ON OPHELIMITY, UTILITY AND } \\
\text { WELFARE: IMPLICATIONS FOR PUBLIC FINANCE }\end{array}$ \\
\hline 09.14 & Weber, E.J. & $\begin{array}{l}\text { WILFRED EDWARD GRAHAM SALTER: THE MERITS OF A } \\
\text { CLASSICAL ECONOMIC EDUCATION }\end{array}$ \\
\hline 09.15 & Tyers, R. and Huang, L. & $\begin{array}{l}\text { COMBATING CHINA'S EXPORT CONTRACTION: FISCAL } \\
\text { EXPANSION OR ACCELERATED INDUSTRIAL REFORM }\end{array}$ \\
\hline 09.16 & $\begin{array}{l}\text { Zweifel, P., Plaff, D. and } \\
\text { Kühn, J. }\end{array}$ & $\begin{array}{l}\text { IS REGULATING THE SOLVENCY OF BANKS COUNTER- } \\
\text { PRODUCTIVE? }\end{array}$ \\
\hline 09.17 & Clements, $\mathrm{K}$. & THE PHD CONFERENCE REACHES ADULTHOOD \\
\hline 09.18 & McLure, M. & $\begin{array}{l}\text { THIRTY YEARS OF ECONOMICS: UWA AND THE WA } \\
\text { BRANCH OF THE ECONOMIC SOCIETY FROM } 1963 \text { TO } 1992\end{array}$ \\
\hline 09.19 & Harris, R.G. and Robertson, P. & $\begin{array}{l}\text { TRADE, WAGES AND SKILL ACCUMULATION IN THE } \\
\text { EMERGING GIANTS }\end{array}$ \\
\hline 09.20 & $\begin{array}{l}\text { Peng, J., Cui, J., Qin, F. and } \\
\text { Groenewold, N. }\end{array}$ & STOCK PRICES AND THE MACRO ECONOMY IN CHINA \\
\hline 09.21 & Chen, A. and Groenewold, N. & $\begin{array}{l}\text { REGIONAL EQUALITY AND NATIONAL DEVELOPMENT IN } \\
\text { CHINA: IS THERE A TRADE-OFF? }\end{array}$ \\
\hline
\end{tabular}




\section{ECONOMICS DISCUSSION PAPERS}

2010

\begin{tabular}{|c|c|c|}
\hline $\begin{array}{l}\text { DP } \\
\text { NUMBER }\end{array}$ & AUTHORS & TITLE \\
\hline 10.01 & Hendry, D.F. & $\begin{array}{l}\text { RESEARCH AND THE ACADEMIC: A TALE OF } \\
\text { TWO CULTURES }\end{array}$ \\
\hline 10.02 & McLure, M., Turkington, D. and Weber, E.J. & A CONVERSATION WITH ARNOLD ZELLNER \\
\hline 10.03 & $\begin{array}{l}\text { Butler, D.J., Burbank, V.K. and } \\
\text { Chisholm, J.S. }\end{array}$ & $\begin{array}{l}\text { THE FRAMES BEHIND THE GAMES: PLAYER'S } \\
\text { PERCEPTIONS OF PRISONER'S DILEMMA, } \\
\text { CHICKEN, DICTATOR, AND ULTIMATUM GAMES }\end{array}$ \\
\hline 10.04 & Harris, R.G., Robertson, P.E. and Xu, J.Y. & $\begin{array}{l}\text { THE INTERNATIONAL EFFECTS OF CHINA'S } \\
\text { GROWTH, TRADE AND EDUCATION BOOMS }\end{array}$ \\
\hline 10.05 & Clements, K.W., Mongey, S. and Si, J. & $\begin{array}{l}\text { THE DYNAMICS OF NEW RESOURCE PROJECTS } \\
\text { A PROGRESS REPORT }\end{array}$ \\
\hline 10.06 & Costello, G., Fraser, P. and Groenewold, N. & $\begin{array}{l}\text { HOUSE PRICES, NON-FUNDAMENTAL } \\
\text { COMPONENTS AND INTERSTATE SPILLOVERS: } \\
\text { THE AUSTRALIAN EXPERIENCE }\end{array}$ \\
\hline 10.07 & Clements, $\mathrm{K}$. & $\begin{array}{l}\text { REPORT OF THE } 2009 \text { PHD CONFERENCE IN } \\
\text { ECONOMICS AND BUSINESS }\end{array}$ \\
\hline 10.08 & Robertson, P.E. & $\begin{array}{l}\text { INVESTMENT LED GROWTH IN INDIA: HINDU } \\
\text { FACT OR MYTHOLOGY? }\end{array}$ \\
\hline 10.09 & Fu, D., Wu, Y. and Tang, Y. & $\begin{array}{l}\text { THE EFFECTS OF OWNERSHIP STRUCTURE AND } \\
\text { INDUSTRY CHARACTERISTICS ON EXPORT } \\
\text { PERFORMANCE }\end{array}$ \\
\hline 10.10 & Wu, Y. & $\begin{array}{l}\text { INNOVATION AND ECONOMIC GROWTH IN } \\
\text { CHINA }\end{array}$ \\
\hline 10.11 & Stephens, B.J. & $\begin{array}{l}\text { THE DETERMINANTS OF LABOUR FORCE } \\
\text { STATUS AMONG INDIGENOUS AUSTRALIANS }\end{array}$ \\
\hline 10.12 & Davies, M. & $\begin{array}{l}\text { FINANCING THE BURRA BURRA MINES, SOUTH } \\
\text { AUSTRALIA: LIQUIDITY PROBLEMS AND } \\
\text { RESOLUTIONS }\end{array}$ \\
\hline 10.13 & Tyers, R. and Zhang, Y. & APPRECIATING THE RENMINBI \\
\hline 10.14 & Clements, K.W., Lan, Y. and Seah, S.P. & $\begin{array}{l}\text { THE BIG MAC INDEX TWO DECADES ON } \\
\text { AN EVALUATION OF BURGERNOMICS }\end{array}$ \\
\hline 10.15 & Robertson, P.E. and Xu, J.Y. & $\begin{array}{l}\text { IN CHINA'S WAKE: } \\
\text { HAS ASIA GAINED FROM CHINA'S GROWTH? }\end{array}$ \\
\hline 10.16 & Clements, K.W. and Izan, H.Y. & $\begin{array}{l}\text { THE PAY PARITY MATRIX: A TOOL FOR } \\
\text { ANALYSING THE STRUCTURE OF PAY }\end{array}$ \\
\hline 10.17 & Gao, G. & WORLD FOOD DEMAND \\
\hline 10.18 & Wu, Y. & $\begin{array}{l}\text { INDIGENOUS INNOVATION IN CHINA: } \\
\text { IMPLICATIONS FOR SUSTAINABLE GROWTH }\end{array}$ \\
\hline 10.19 & Robertson, P.E. & DECIPHERING THE HINDU GROWTH EPIC \\
\hline 10.20 & Stevens, G. & $\begin{array}{l}\text { RESERVE BANK OF AUSTRALIA-THE ROLE OF } \\
\text { FINANCE }\end{array}$ \\
\hline 10.21 & Widmer, P.K., Zweifel, P. and Farsi, M. & $\begin{array}{l}\text { ACCOUNTING FOR HETEROGENEITY IN THE } \\
\text { MEASUREMENT OF HOSPITAL PERFORMANCE }\end{array}$ \\
\hline 10.22 & McLure, M. & $\begin{array}{l}\text { ASSESSMENTS OF A. C. PIGOU'S FELLOWSHIP } \\
\text { THESES }\end{array}$ \\
\hline
\end{tabular}




\begin{tabular}{|l|l|l|}
\hline 10.23 & Poon, A.R. & $\begin{array}{l}\text { THE ECONOMICS OF NONLINEAR PRICING: } \\
\text { EVIDENCE FROM AIRFARES AND GROCERY } \\
\text { PRICES }\end{array}$ \\
\hline 10.24 & Halperin, D. & $\begin{array}{l}\text { FORECASTING METALS RETURNS: A BAYESIAN } \\
\text { DECISION THEORETIC APPROACH }\end{array}$ \\
\hline 10.25 & Clements, K.W. and Si. J. & $\begin{array}{l}\text { THE INVESTMENT PROJECT PIPELINE: COST } \\
\text { ESCALATION, LEAD-TIME, SUCCESS, FAILURE } \\
\text { AND SPEED }\end{array}$ \\
\hline 10.26 & Chen, A., Groenewold, N. and Hagger, A.J. & $\begin{array}{l}\text { THE REGIONAL ECONOMIC EFFECTS OF A } \\
\text { REDUCTION IN CARBON EMISSIONS }\end{array}$ \\
\hline 10.27 & $\begin{array}{l}\text { Siddique, A., Selvanathan, E.A. and } \\
\text { Selvanathan, S. }\end{array}$ & $\begin{array}{l}\text { REMITTANCES AND ECONOMIC GROWTH: } \\
\text { EMPIRICAL EVIDENCE FROM BANGLADESH, } \\
\text { INDIA AND SRI LANKA }\end{array}$ \\
\hline
\end{tabular}




\section{ECONOMICS DISCUSSION PAPERS}

2011

\begin{tabular}{|c|c|c|}
\hline $\begin{array}{l}\text { DP } \\
\text { NUMBER }\end{array}$ & AUTHORS & TITLE \\
\hline 11.01 & Robertson, P.E. & $\begin{array}{l}\text { DEEP IMPACT: CHINA AND THE WORLD } \\
\text { ECONOMY }\end{array}$ \\
\hline 11.02 & Kang, C. and Lee, S.H. & $\begin{array}{l}\text { BEING KNOWLEDGEABLE OR SOCIABLE? } \\
\text { DIFFERENCES IN RELATIVE IMPORTANCE OF } \\
\text { COGNITIVE AND NON-COGNITIVE SKILLS }\end{array}$ \\
\hline 11.03 & Turkington, D. & DIFFERENT CONCEPTS OF MATRIX CALCULUS \\
\hline 11.04 & Golley, J. and Tyers, R. & $\begin{array}{l}\text { CONTRASTING GIANTS: DEMOGRAPHIC CHANGE } \\
\text { AND ECONOMIC PERFORMANCE IN CHINA AND } \\
\text { INDIA }\end{array}$ \\
\hline 11.05 & Collins, J., Baer, B. and Weber, E.J. & $\begin{array}{l}\text { ECONOMIC GROWTH AND EVOLUTION: } \\
\text { PARENTAL PREFERENCE FOR QUALITY AND } \\
\text { QUANTITY OF OFFSPRING }\end{array}$ \\
\hline 11.06 & Turkington, D. & $\begin{array}{l}\text { ON THE DIFFERENTIATION OF THE LOG } \\
\text { LIKELIHOOD FUNCTION USING MATRIX } \\
\text { CALCULUS }\end{array}$ \\
\hline 11.07 & Groenewold, N. and Paterson, J.E.H. & $\begin{array}{l}\text { STOCK PRICES AND EXCHANGE RATES IN } \\
\text { AUSTRALIA: ARE COMMODITY PRICES THE } \\
\text { MISSING LINK? }\end{array}$ \\
\hline 11.08 & Chen, A. and Groenewold, N. & $\begin{array}{l}\text { REDUCING REGIONAL DISPARITIES IN CHINA: IS } \\
\text { INVESTMENT ALLOCATION POLICY EFFECTIVE? }\end{array}$ \\
\hline 11.09 & Williams, A., Birch, E. and Hancock, P. & $\begin{array}{l}\text { THE IMPACT OF ON-LINE LECTURE RECORDINGS } \\
\text { ON STUDENT PERFORMANCE }\end{array}$ \\
\hline 11.10 & Pawley, J. and Weber, E.J. & $\begin{array}{l}\text { INVESTMENT AND TECHNICAL PROGRESS IN THE } \\
\text { G7 COUNTRIES AND AUSTRALIA }\end{array}$ \\
\hline 11.11 & Tyers, R. & $\begin{array}{l}\text { AN ELEMENTAL MACROECONOMIC MODEL FOR } \\
\text { APPLIED ANALYSIS AT UNDERGRADUATE LEVEL }\end{array}$ \\
\hline 11.12 & Clements, K.W. and Gao, G. & QUALITY, QUANTITY, SPENDING AND PRICES \\
\hline 11.13 & Tyers, R. and Zhang, Y. & $\begin{array}{l}\text { JAPAN'S ECONOMIC RECOVERY: INSIGHTS FROM } \\
\text { MULTI-REGION DYNAMICS }\end{array}$ \\
\hline 11.14 & McLure, M. & A. C. PIGOU'S REJECTION OF PARETO'S LAW \\
\hline 11.15 & Kristoffersen, I. & $\begin{array}{l}\text { THE SUBJECTIVE WELLBEING SCALE: HOW } \\
\text { REASONABLE IS THE CARDINALITY } \\
\text { ASSUMPTION? }\end{array}$ \\
\hline 11.16 & Clements, K.W., Izan, H.Y. and Lan, Y. & VOLATILITY AND STOCK PRICE INDEXES \\
\hline 11.17 & Parkinson, $\mathrm{M}$. & $\begin{array}{l}\text { SHANN MEMORIAL LECTURE 2011: SUSTAINABLE } \\
\text { WELLBEING - AN ECONOMIC FUTURE FOR } \\
\text { AUSTRALIA }\end{array}$ \\
\hline 11.18 & Chen, A. and Groenewold, N. & $\begin{array}{l}\text { THE NATIONAL AND REGIONAL EFFECTS OF } \\
\text { FISCAL DECENTRALISATION IN CHINA }\end{array}$ \\
\hline 11.19 & Tyers, R. and Corbett, J. & $\begin{array}{l}\text { JAPAN'S ECONOMIC SLOWDOWN AND ITS } \\
\text { GLOBAL IMPLICATIONS: A REVIEW OF THE } \\
\text { ECONOMIC MODELLING }\end{array}$ \\
\hline 11.20 & Wu, Y. & $\begin{array}{l}\text { GAS MARKET INTEGRATION: GLOBAL TRENDS } \\
\text { AND IMPLICATIONS FOR THE EAS REGION }\end{array}$ \\
\hline 11.21 & Fu, D., Wu, Y. and Tang, Y. & $\begin{array}{l}\text { DOES INNOVATION MATTER FOR CHINESE HIGH- } \\
\text { TECH EXPORTS? A FIRM-LEVEL ANALYSIS }\end{array}$ \\
\hline
\end{tabular}




\begin{tabular}{|l|l|l|}
\hline 11.22 & Fu, D. and Wu, Y. & $\begin{array}{l}\text { EXPORT WAGE PREMIUM IN CHINA'S } \\
\text { MANUFACTURING SECTOR: A FIRM LEVEL } \\
\text { ANALYSIS }\end{array}$ \\
\hline 11.23 & Li, B. and Zhang, J. & $\begin{array}{l}\text { SUBSIDIES IN AN ECONOMY WITH ENDOGENOUS } \\
\text { CYCLES OVER NEOCLASSICAL INVESTMENT AND } \\
\text { NEO-SCHUMPETERIAN INNOVATION REGIMES }\end{array}$ \\
\hline 11.24 & Krey, B., Widmer, P.K. and Zweifel, P. & $\begin{array}{l}\text { EFFICIENT PROVISION OF ELECTRICITY FOR THE } \\
\text { UNITED STATES AND SWITZERLAND }\end{array}$ \\
\hline 11.25 & Wu, Y. & $\begin{array}{l}\text { ENERGY INTENSITY AND ITS DETERMINANTS IN } \\
\text { CHINA'S REGIONAL ECONOMIES }\end{array}$ \\
\hline & & \\
\hline
\end{tabular}

